\title{
The Brazilian sea-level curves: a critical review with emphasis on the curves from the Paranaguá and Cananéia regions
}

\author{
Rodolfo José Angulo ${ }^{\mathrm{a}, 1}$, Guilherme Camargo Lessa ${ }^{\mathrm{b}, *}$ \\ a Departamento de Geologia, Universidade Federal do Paraná, C.P. 19011, Curitiba 81531-990, Brazil

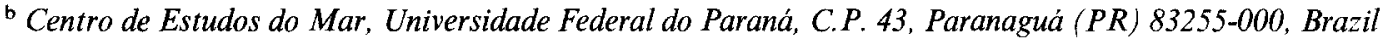 \\ Received 1 August 1996; accepted 10 February 1997
}

\begin{abstract}
Relative sea-level curves for the mid- to late-Holocene have been proposed for eight different sectors along the Brazilian coast. This paper aims to review the data used to construct the curves proposed for two sectors, the Paranaguá and Cananéia regions in southeast Brazil. More specifically, we analyze the palaeo-sea-level indicators (vermetid tubes, shells, wood fragments and shell-midden deposits) related to (1) the sea-level maximum of the midHolocene and (2) the two secondary oscillations that would have occurred between $4100-3800$ years B.P. and $3000-2700$ years B.P. The sedimentary deposits of the coastal plain as well as vermetid datings suggest a midHolocene sea-level maximum between +3.5 and $+4 \mathrm{~m}$. The great majority of the indicators used to infer the secondary oscillations in previous studies were derived from shell middens. Besides being unreliable palaeo-sea-level indicators, these data also showed inconsistencies that undermine the existence of such oscillations. The plot of all the data derived from vermetid samples found along the Brazilian coast also indicate a rather smoother sea-level fall in the last 5100 years. (C) 1997 Elsevier Science B.V.
\end{abstract}

Keywords: Holocene; radiocarbon dating; shell middens

\section{Introduction}

Pioneering studies trying to establish a Holocene mean sea level (MSL) curve for Brazil date back 30 years, when a series of radiocarbon datings of palaeo-sea level indicators were published by van Andel and Laborel (1964) and Delibrias and Laborel (1969). The dated indicators, most of

\footnotetext{
* Corresponding author. Present address: Curso de PósGraduação em Geologia - UFBa, R. Caetano Moura 123, Federação, Salvador (BA) 41210-340, Brazil. Fax: +55 71247 3004; e-mail: glessa@pppg.ufba.br

${ }^{1}$ Fax: 55412662393.
}

them represented by vermetid samples, came from various localities, spanning the coastline from Recife to Angra dos Reis (Fig. 1). Because elevated vermetid lines were observed throughout the Brazilian coast, Delibrias and Laborel (1969) suggested that the results of the 18 datings spanning 6000 years could be representative of the overall mid- to late-Holocene MSL trend along the Brazilian coast. The trend suggested that sea level exceeded the present MSL by 6000 years B.P., reached $+3.0 \mathrm{~m}$ by 4500 years B.P. and then fell gradually to the present level.

Although the sea-level course proposed by Delibrias and Laborel (1969) was derived from 


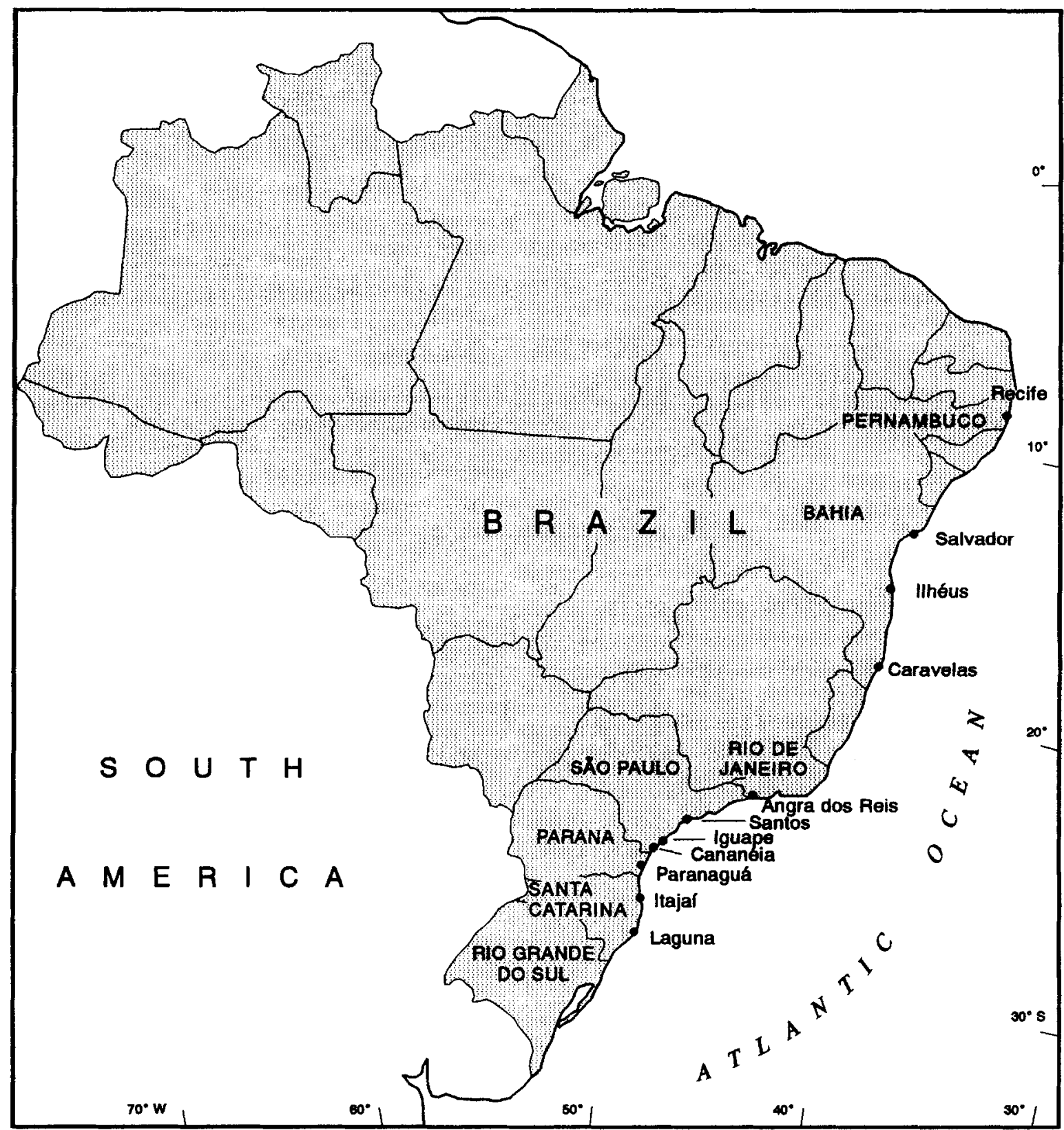

Fig. 1. Location of the sites where sea level studies have been undertaken in Brazil.

widely separated areas, it proved to be somewhat similar to the trend suggested by regional sea-level curves (Figs. 1 and 2). Suguio and Martin (1976) and Martin and Suguio (1976) made the first real attempt to develop a sea-level curve with dated samples from sedimentary (wood fragments and shells) and shell-midden deposits from the Cananéia coastal plain (an updated version of this curve is given in Fig. 2f). Since then, eight other regional curves have been proposed for different sites along the Brazilian coast. It is observed in Fig. 2 that the curves between Salvador and Itajaí 


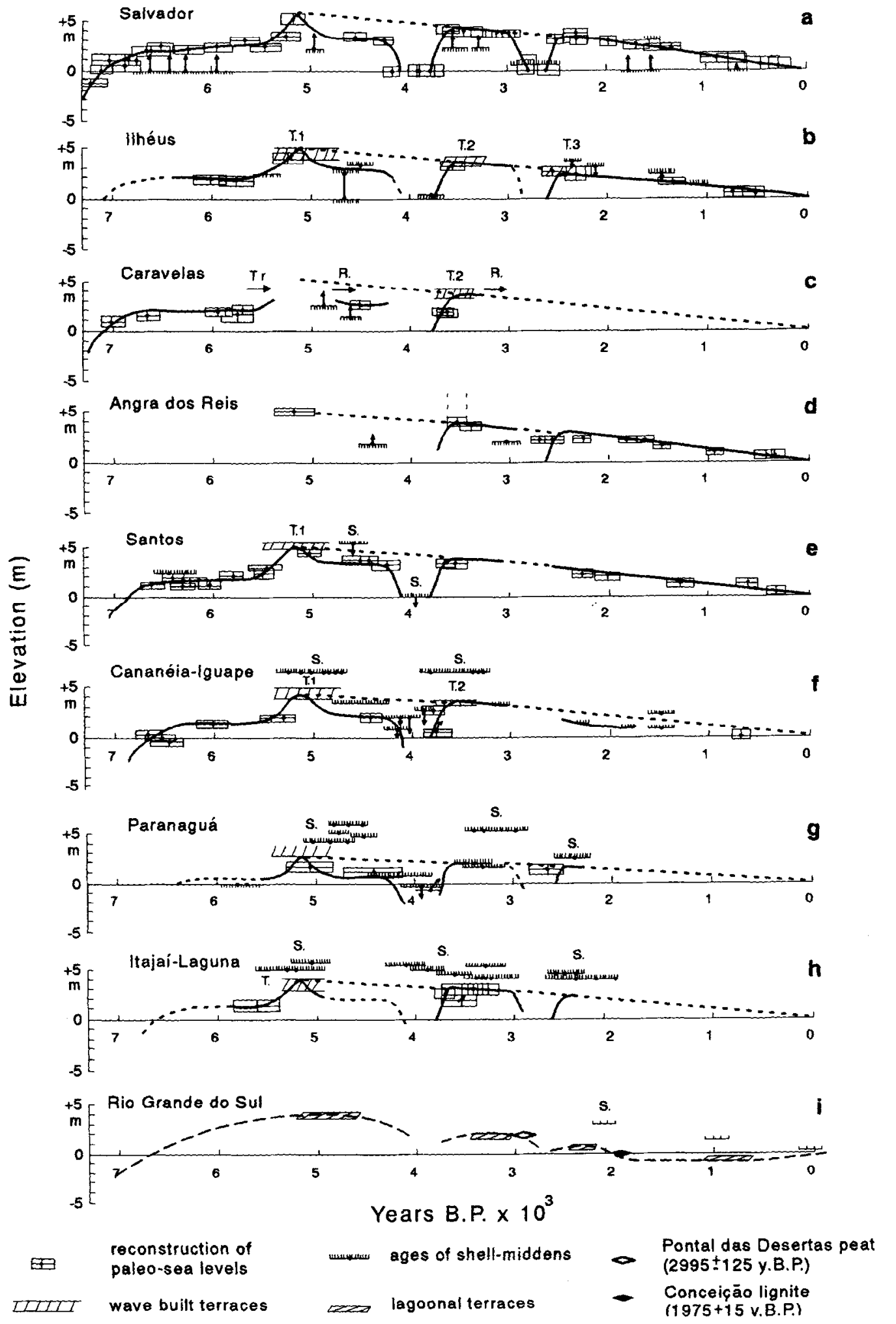

Fig. 2. The Brazilian sea-level curves for the last 7000 years (after Suguio et al., 1985; Villwock and Tomazelli, 1989; Tomazelli, 1990) (see Fig. 1 for location). 


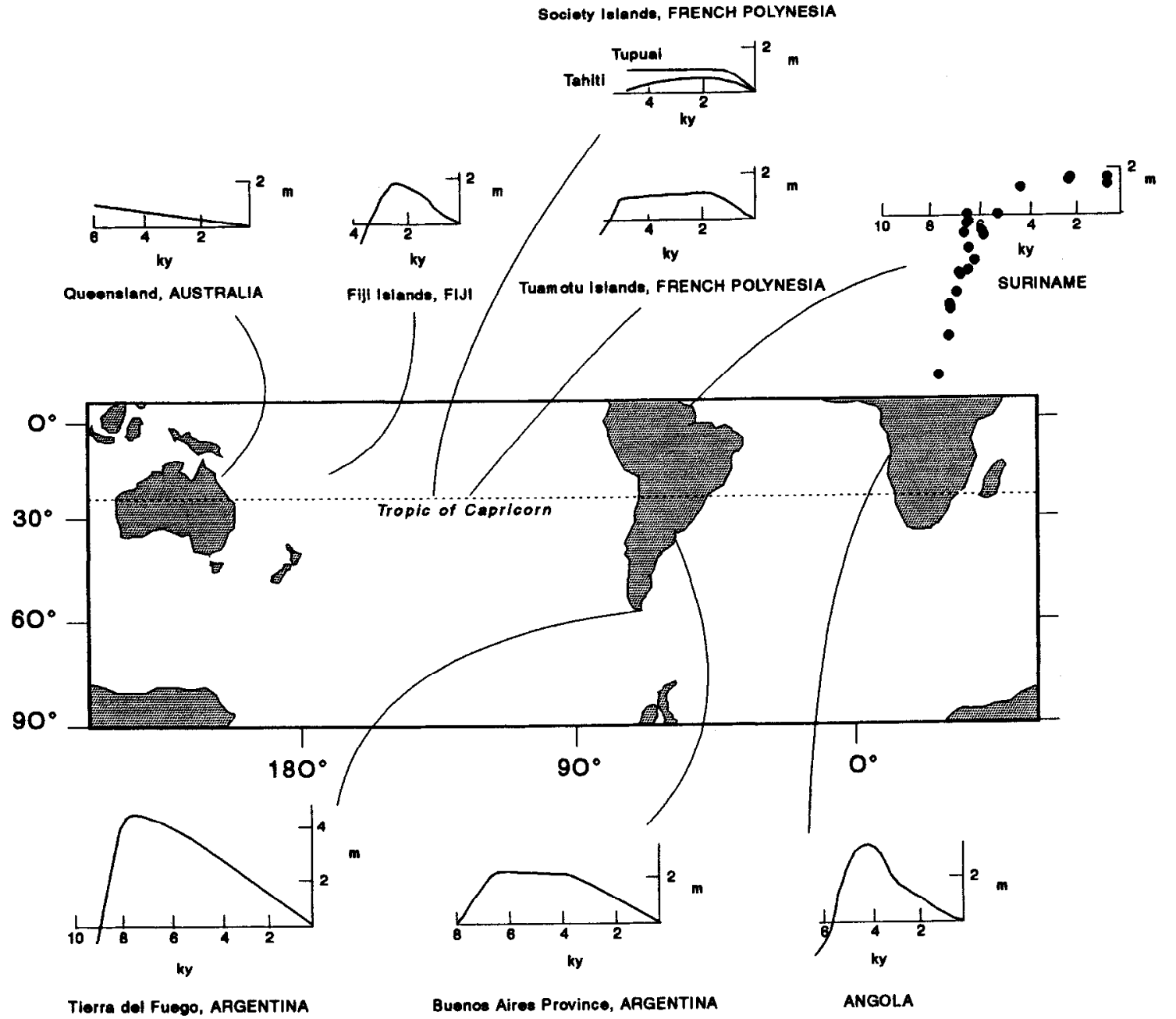

Fig. 3. Holocene sea-level curves in the Southern Hemisphere (after Isla, 1989, and Pirazzoli, 1991), showing no evidence of higher-frequency oscillations in the last 5000 years.

(Fig. 2a-h) follow the same general trend: a general fall of sea level after a maximum of about $5 \mathrm{~m}$ at the post-glacial marine transgression (PMT) around 5100 years B.P., intercalated with two intervals of negative oscillations when sea level may have been at or below the present elevation (4100-3800 and 3000-2700 years B.P.) (Suguio et al., 1985). The last curve (Fig. 2i), proposed for the southernmost Brazilian state, is somewhat different. With a limited number of datings, it suggests that sea level reached a minimum of $-1.5 \mathrm{~m}$ at 1500 years B.P. and has been rising since then (Villwock and Tomazelli, 1989; Tomazelli, 1990; Angulo and Suguio, 1995).

Sea-level curves in the Southern Hemisphere for the last 7000 years are characterized by either a falling or a fluctuating trend (Isla, 1989; Pirazzoli, 1991). Higher-than-present mean sea level at the end of the PMT, with heights varying from 1 to $5 \mathrm{~m}$, appear to have occurred throughout the Southern Hemisphere, but with a time lag towards the Equator (Isla, 1989) (Fig. 3). Secondary oscillations of the MSL that occurred after the end of the PMT are also observed in many curves, 
although most of the oscillations are poorly established (Pirazzoli, 1991). The secondary oscillations in Brazil are suggested to have occurred along a latitudinal span of about 18 degrees, between Salvador in the north and Laguna in the south (Suguio et al., 1985; Tomazelli and Vilwock in Angulo and Suguio, 1995; Tomazelli and Vilwock 1989 in Tomazelli, 1990) (Fig. 1). The oscillations presented by Suguio et al. (1985) comprise about $5 \mathrm{~m}$ of amplitude and extend over a significantly broad area. Given the large spatial extent of this similar sea-level trend, it is expected that cognate sea-level patterns should be observed in neighbouring regions, either to the north or south. An inspection of other published curves in South America shows that there is hardly any coincidence of other curve shapes with that of Brazil (Fig. 3). Exceptions are two curves (Urien, 1970 and Farinati, 1984, in Pirazzoli, 1991) that show oscillations of more than $5 \mathrm{~m}$, which are, however, of doubtful validity due to the nature of the data utilized (Pirazzoli, 1991).

The purpose of this work is the re-evaluation of the sea-level data used by other authors to determine the maximum elevation of the Holocene transgression and the two secondary oscillations (4100-3800 and 3000-2700 years B.P.) in the Cananéia and Paranaguá regions. By critically reviewing key indicators from these two areas, this study attempts first to re-assess the validity of the sea-level curves in these two regions, and second, to contribute to the calibration of the other Brazilian sea-level curves.

\section{Study area}

The study area encompasses most of the coastal plain of the State of Parana and the southern part of São Paulo State (Fig. 4), with a N-S extension of about $200 \mathrm{~km}$. This coastal plain can be divided into three distinct sectors, separated by coastal ranges that run almost normal to the coastline: (1) Guaratuba, in the south of the State of Paraná; (2) Paranaguá-Superagui, that extends up to the border of the State of São Paulo; and (3) the Cananéia coastal plain.

Studies of the Quaternary geology and evolution of the area span the last 50 years in Guaratuba and Paranaguá (Bigarella, 1946; Rivereau et al., 1968, 1969a,b,c,d,e, 1970; Bigarella et al., 1978; Martin et al., 1988; Angulo, 1992; Lessa and Angulo, 1995), but have begun more recently in Cananéia (Petri and Suguio, 1973; Suguio and Petri, 1973; Barcelos, 1975; Suguio and Martin, 1978a, b; Suguio and Barcelos, 1978; Ponçano, 1981; Souza, 1995). Similar to what is observed along most of the Brazilian coastline (Suguio et al., 1985), the coastal plains show evidence of the regression that followed the sea-level maxima of 120,000 years B.P. and 5100 years B.P. (Suguio and Martin, 1978a,b; Martin et al., 1988; Angulo, 1992).

In the Paranaguá-Superagui sector beach ridges are the predominant morphological feature of the coastal plain. Martin et al. (1988) and Angulo (1992) have subdivided the ridges between Pleistocene and Holocene ages, but their suggested boundaries are different (see Fig. 5). Based on logs from water wells, Lessa and Angulo (1995) proposed a preliminary evolutionary model for the Paranaguá coastal plain, with the existence of transgressive and regressive sequences comprising marine sands and estuarine muds. In the whole region, the Holocene strandplain appears to have evolved into an encroachment mode (Roy et al., 1995) against the Pleistocene strandplain in the later stages of the PMT. No true lagoonal depression in the back of the Holocene strandplain is observed, although palaeo-lagoonal deposits are found underneath the present shoreline at depths around $-10 \mathrm{~m}$ (Lessa and Angulo, 1995). The low-lying area within the Paranaguá coastal plain located behind the Holocene strandplain is actually an erosive platform of the Guaraguaçu River constructed upon the Pleistocene strandplain (Lessa and Angulo, in prep.). Corings performed across the valley show an entirely sandy substrate with (sub)horizontal plane-parallel structures characteristic of a beach-face environment (Lessa and Angulo, in prep.).

In Cananeia, the major part of the coastal plain is composed of a dissected Pleistocene strandplain (Suguio and Martin, 1978b). An evolutionary model for the coastal plain that covers the last 120,000 years (Fig. 6) shows that a beach ridge 


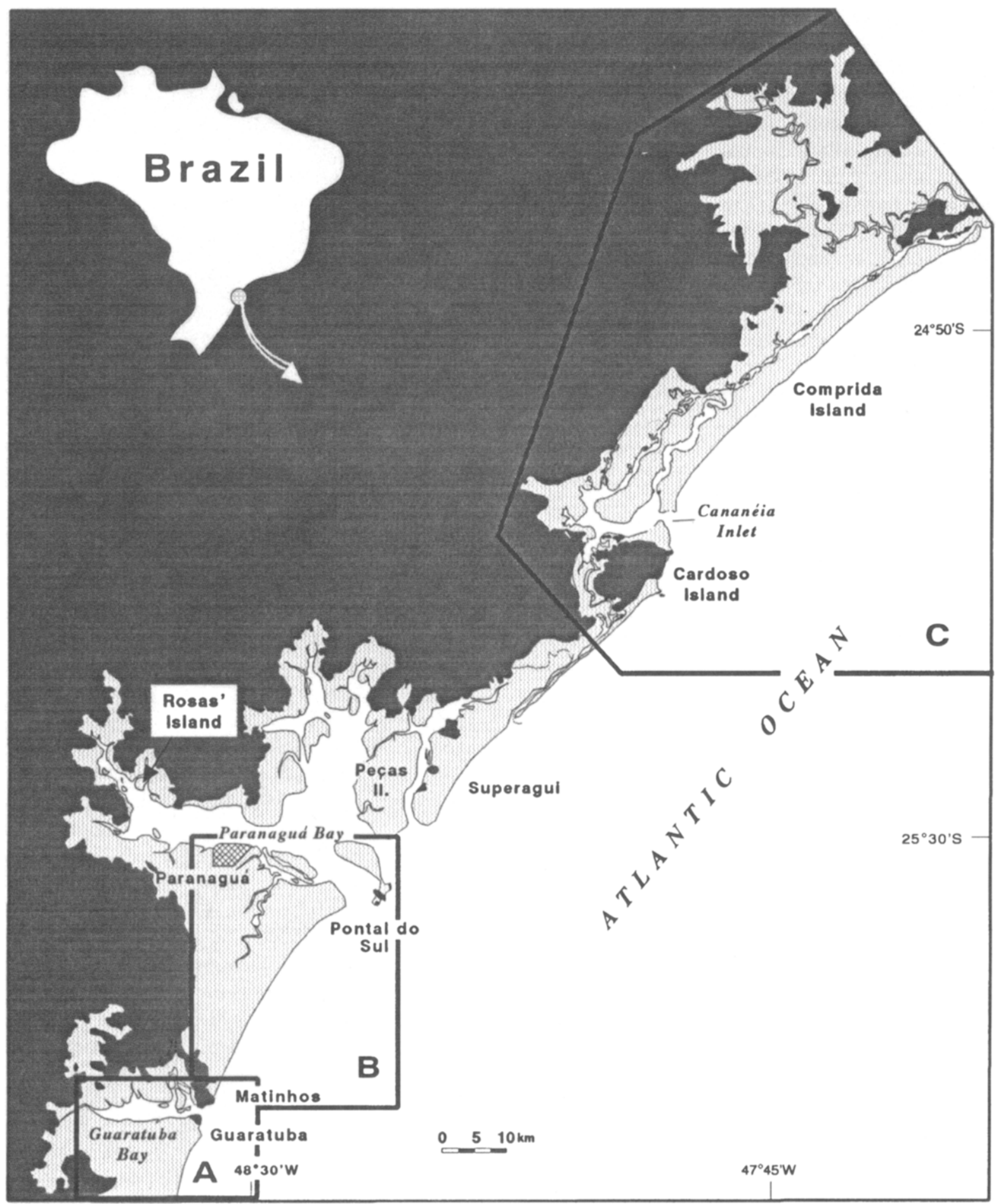


plain was formed during regressive episodes (Suguio and Martin, 1978a). During marine lowstands, fluvial erosion carved valleys parallel to the shoreline that were later infilled by sedimentation associated with the subsequent rise of sea level (Fig. 6). Also according to this model, a translating barrier should not be preserved at the shoreface accompanying sea-level rise. Instead, the only feature associated with the PMT is an erosion platform on the pre-existing barrier.

During the secondary Holocene sea-level fluctuations at 4100 and 3500 years B.P., other generations of beach ridges were formed on Comprida Island (Fig. 4C) (Suguio and Martin, 1978a). These authors identify "at least two generations of beach ridges separated by a more or less swampy, low-lying zone that can be followed about $50 \mathrm{~km}$ ", parallel to the coastline.

\section{Published key palaeo-sea-level indicators}

\subsection{Guaratuba and Paranaguá coastal plains}

The first datings reported for this region are related to archaeological studies in shell-middens. Laming-Emperaire (1968) studied a midden located on Rosas' Island (Fig. 4), at a place currently beneath a small human settlement that up to the 19th century utilized the midden as raw material for a kiln. Three shell samples at the lower part of the midden were dated at $3150 \pm 110$ (Gif. 1047), 2480 \pm 110 (Gif. 1046) and 2500 \pm 110 years B.P. (Table 1), the first one located close to the present low tide level. Since human settlements are assumed to occur above the high tide level, Laming-Emperaire (1968) interpreted that sea level during the time of the midden occupation was below the present elevation.
Martin et al. (1988) indicated that the midden rests on a rock outcrop submerged during high tide, and that the lowest layer of the midden $(3150 \pm 110$ years B.P.) is overlain by estuarine deposits, which in turn underlie a second layer of midden shells ( 2480 years B.P. \pm 110 ). Martin et al. (1988) suggested that the presence of estuarine sediments capping the first layer of the midden is an indication that sea level was rising at about 3100 years B.P., and that the second layer of shells was laid down with a falling sea level after a maximum that occurred before 2500 years B.P.

In the Boguaçu River (Fig. 4A) Martin et al. (1988) dated mollusc shells from a shell-midden whose base is presently underwater. The shells were collected at the present MSL, and dated at $3920 \pm 190$ years B.P. (Bah. 1272), suggesting that sea level was below the present elevation by that time.

Bigarella (1971) dated typical open marine shells (SI 237) (Donax and Arca amongst others, J.J. Bigarella, pers. commun., 1990) retrieved from a coring performed on the Caiobá tombolo (Fig. 4), whose surface lies approximately $2 \mathrm{~m}$ above MSL (Fig. 7). The shells were embedded in muddy sediments buried under $4 \mathrm{~m}$ (i.e., at $-2 \mathrm{~m}$ ) of marine sand, and provided an age of 3830 years B.P. Bigarella (1971) interpreted the deposit as being associated with a sea level higher than today, whereas Martin et al. (1988) proposed that the stratigraphic sequence of the tombolo is transgressive, and that sea level was below the present elevation around 3800 years. The authors imply that the deposit where the shell is embedded, is related to a back-barrier lagoon. According to this scenario, the back-barrier lagoon was buried by a transgressive barrier that accompanied the rise of sea level that ended around 3500 years B.P.

Martin et al. (1988) presented two datings of

Fig. 4. The coastal plain of the states of Paraná and southern São Paulo, and location of the Rosas' Island shell-midden (Gif-1046 and Gif-1047). (A) Marine sedimentary deposits and location of the dated samples from the Guaratuba coastal plain: $1=$ sedimentary deposit (SI-327), 2 =sedimentary deposit (Bah-1277), 3=sedimentary deposit (Bah-1278), 4=vermetid (CENA-140), 5=vermetid (CENA-141), 6= Boguaçu River shell-midden (Bah-1273), 7= Boguaçu River shell-midden (Bah-1272). (B) Marine sedimentary deposits and location of the dated samples from Paranaguá coastal plain: $I=$ sedimentary deposit (Bah-1270), $2=$ sedimentary deposit (Bah-1269), $3=$ vermetid (GSC-5255), 4=vermetid (CENA-143). (C) Marine sedimentary deposits and location of the samples from Cananéia coastal plain: $l=$ sedimentary deposit (Bah-630), $2=$ sedimentary deposit (Bah-445), $3=$ Ararapira channel shellmidden (Bah-289), 4=Ararapira channel shell-midden (Gif-3437), 5=Comprida Island shell-midden (Gif-3436 and Bah-303), $6=$ Tapera-Cananéia shell-midden (Bah-291). 
A

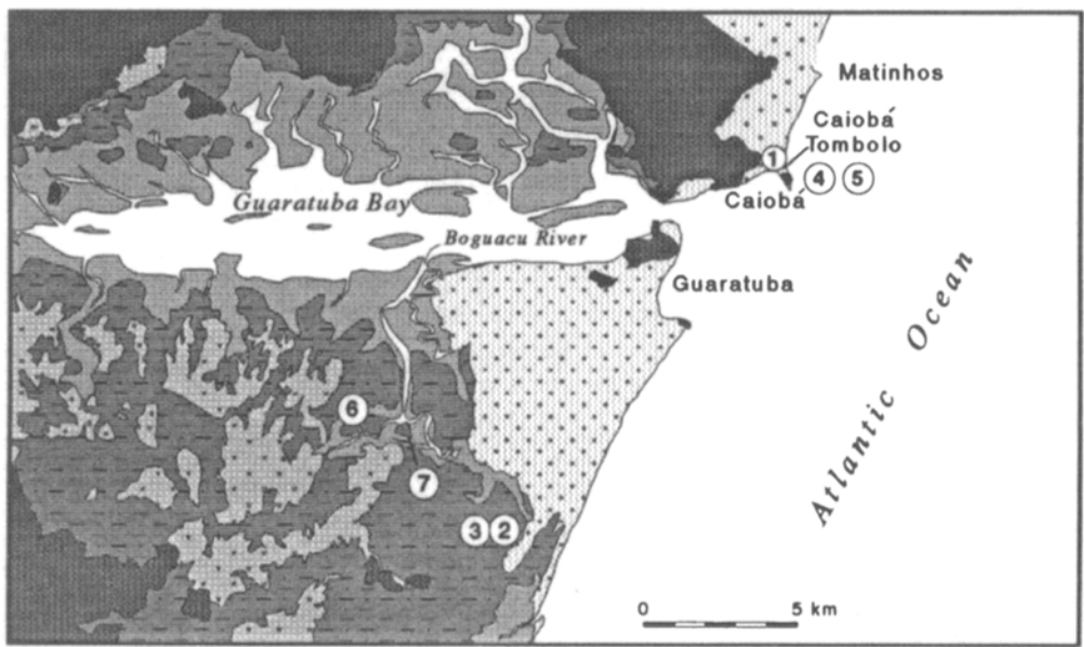

B

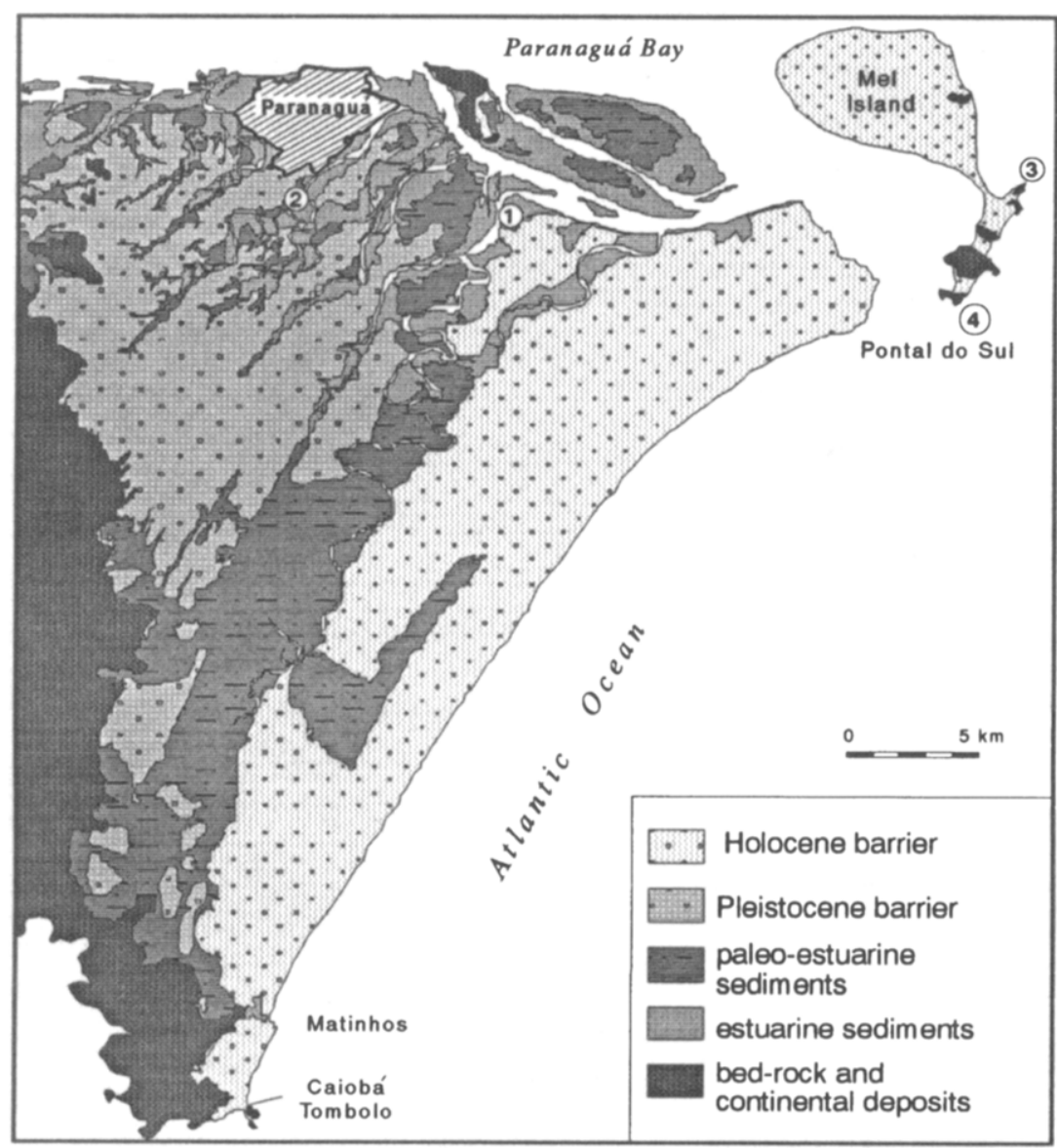




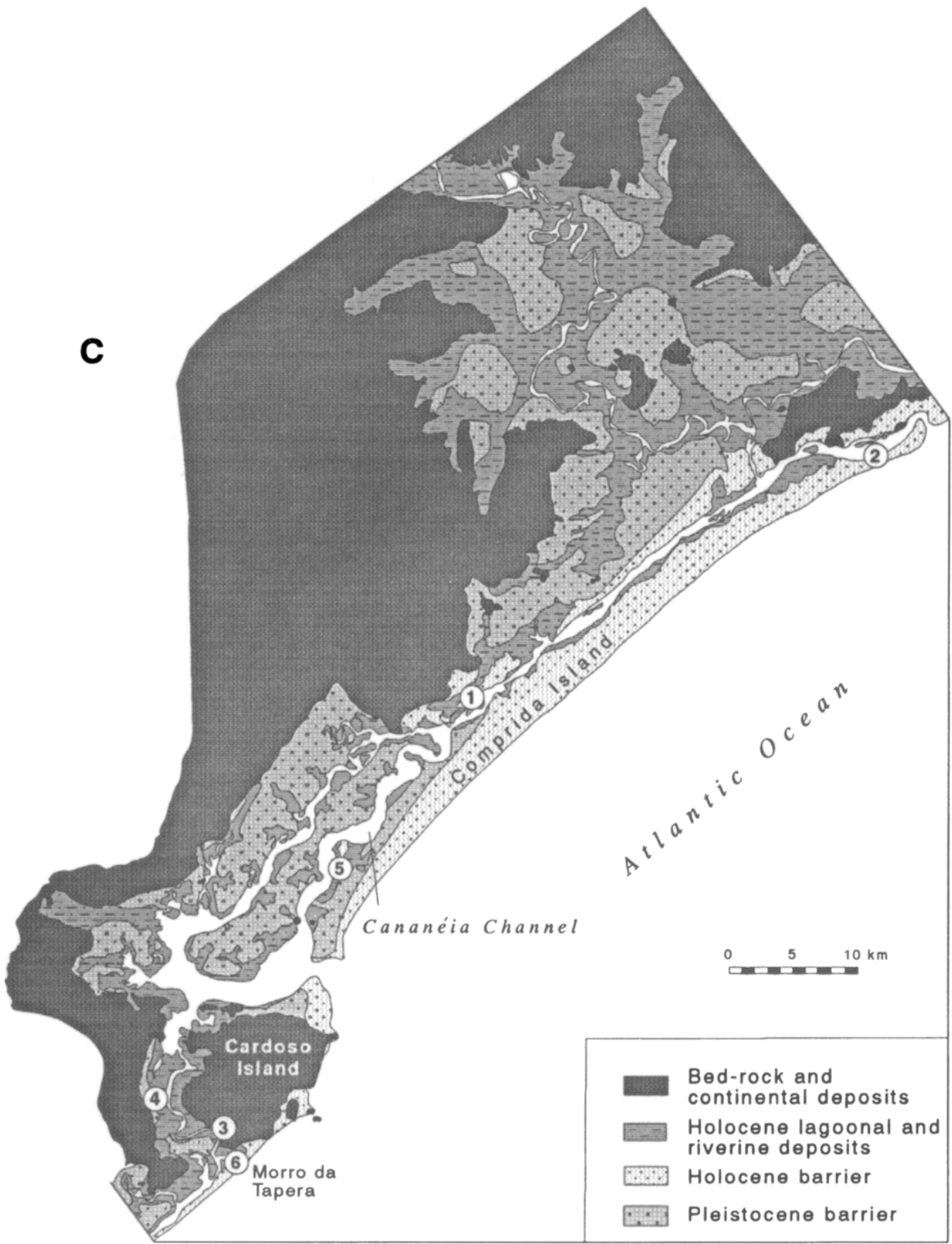




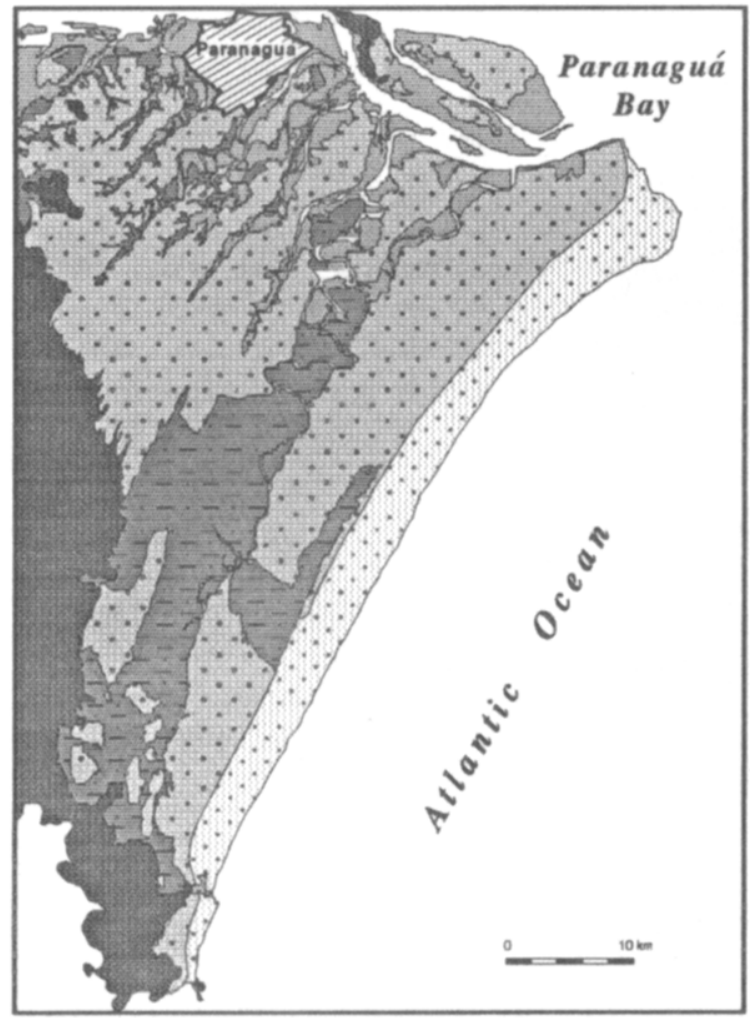

Pleistocene strandplain

$\therefore$ Holocene strandplain

E- lagoonal deposits mangrovee deposits bedrock and continental deposits

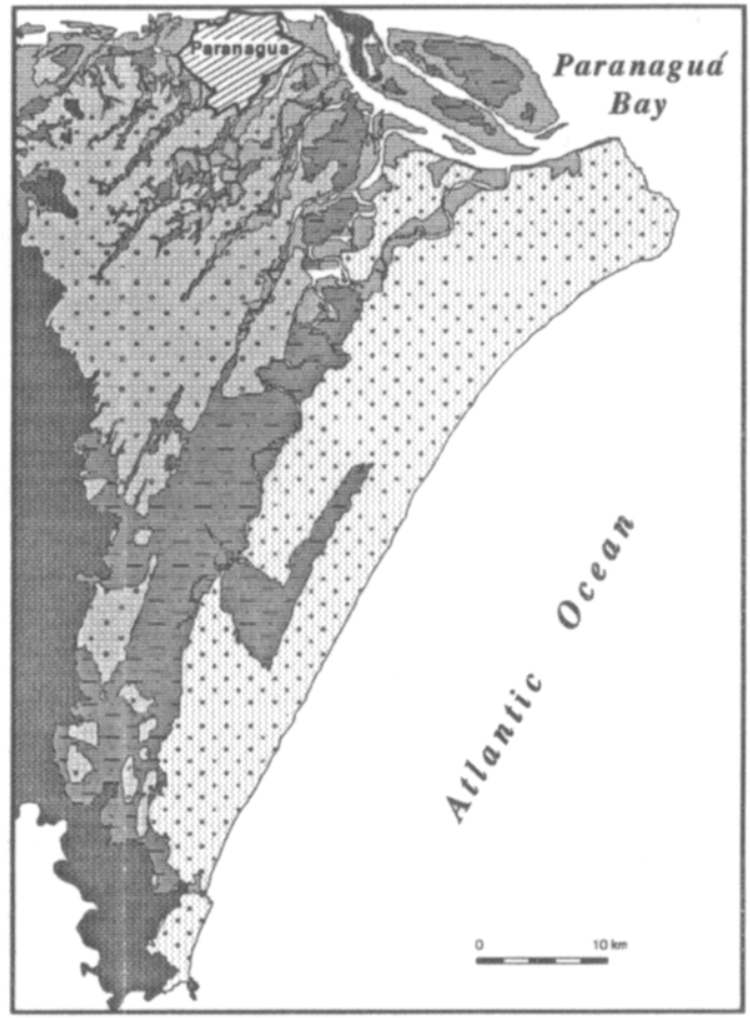

Pleistocene strandplain Holocene strandplain paleo-estuarine deposits estuarine deposits

Fig. 5. Geological map of the Paranaguá costal plain after Martin et al. (1988) and Angulo (1992). Note the partition of the Pleistocene and Holocene strandplains.

mollusc shells located on palaeo-estuarine sediments from the Guaratuba coastal plain (Fig. 4A). These samples were dated at 2970 years B.P. (Bah-1278) and 3160 years B.P. (Bah-1277) (Table 2), and were related to palaeo-sea levels of $>+1.0 \mathrm{~m}$. Since these samples were collected at the surface, Martin et al. (1988) suggested that the palaeo-lagoon could have dried out at approximately 3000 years B.P., after a sea-level fall presumably associated with the secondary oscillation between 3000 and 2700 years B.P.
Two other datings of mollusc shells were presented by Martin et al. (1988) from samples collected in the Itiberê and Guaraguaçu rivers, both located in Paranaguá Bay (Table 2). These samples were dated at 2650 years B.P. (Bah-1269), 2680 years B.P. (Bah-1270), and according to Martin et al. (1988) indicate palaeo-sea levels of $+1 \pm 0.5 \mathrm{~m}$, or sea levels higher than at present.

An inference of a sea-level maximum of about $2.5 \mathrm{~m}$ at the end of the PMT was made by Suguio et al. (1985, 1988) and Martin et al. (1988) based 
A

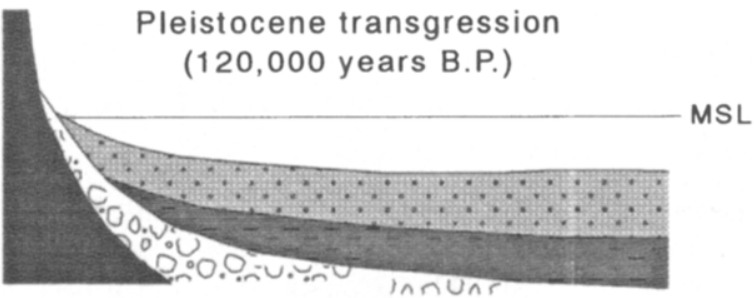

B

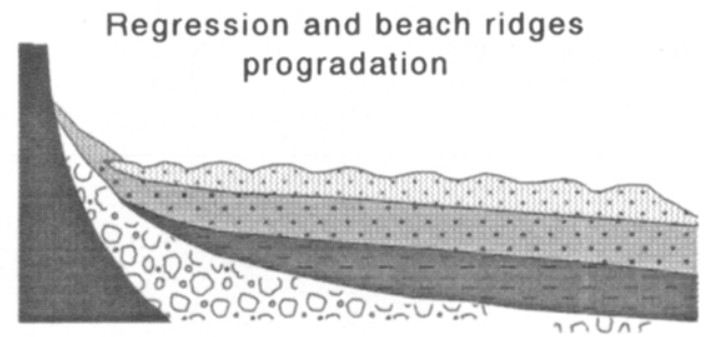

C
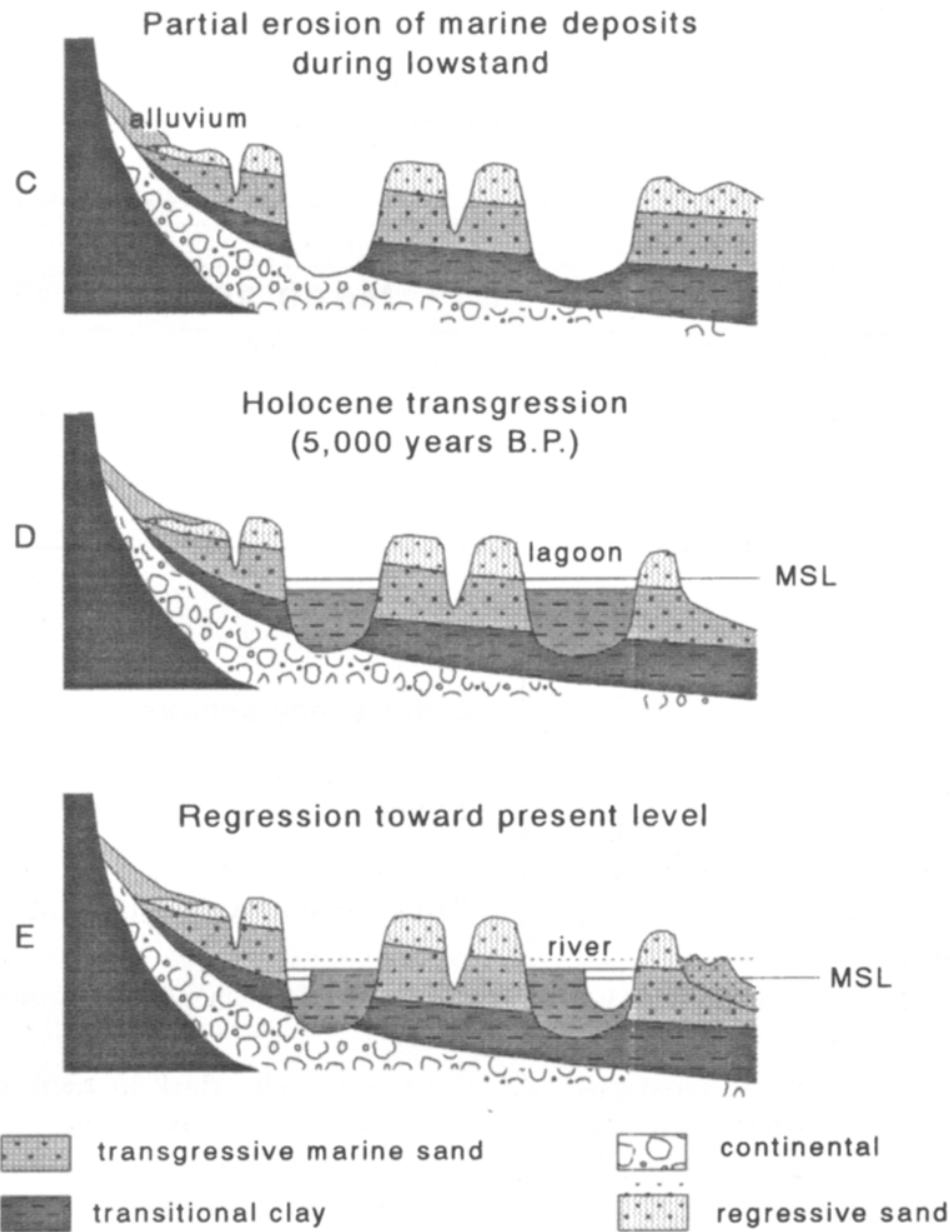

Fig. 6. Evolutionary model for the Cananéia coastal plain (after Suguio and Martin, 1978b). No sand body is associated with rising sea level and marine transgression. The formation of strandplains is allied to falling sea levels. 
Table 1

Radiocarbon datings of shell-midden deposits

\begin{tabular}{lllllll}
\hline Local & $\begin{array}{l}\text { Latitude } \\
\text { (south) }\end{array}$ & $\begin{array}{l}\text { Longitude } \\
\text { (west) }\end{array}$ & $\begin{array}{l}\text { Age } \\
\text { (years B.P.) }\end{array}$ & $\begin{array}{l}\text { Palaeo-level } \\
(\mathrm{m})\end{array}$ & Lab. Ref. No & Source \\
\hline Baguacú River & $25^{\circ} 55^{\prime} 12^{\prime \prime}$ & $48^{\circ} 37^{\prime} 12^{\prime \prime}$ & $3290 \pm 190$ & $<+1.3$ & Bah-1273 & Martin et al., 1988 \\
Boguaçu River & $25^{\circ} 55^{\prime} 24^{\prime \prime}$ & $48^{\circ} 38^{\prime} 18^{\prime \prime}$ & $3920 \pm 190$ & $<0$ & Bah-1272 & Martin et al., 1988 \\
Rosas' Island & $25^{\circ} 25^{\prime} 00^{\prime \prime}$ & $48^{\circ} 39^{\prime} 36^{\prime \prime}$ & $3150 \pm 110$ & $<0$ & Gif-1047 & Laming-Emperaire, 1968 \\
Rosas' Island & $25^{\circ} 25^{\prime} 00^{\prime \prime}$ & $48^{\circ} 39^{\prime} 36^{\prime \prime}$ & $2480 \pm 110$ & $<0$ & Gif-1046 & Laming-Emperaire, 1968 \\
Ararapira Channel & $25^{\circ} 01^{\prime} 30^{\prime \prime}$ & $48^{\circ} 03^{\prime} 30^{\prime \prime}$ & $4130 \pm 100$ & $\cong+0.5$ & Bah-289 & Suguio et al., 1976 \\
Ararapira Channel & $25^{\circ} 09^{\prime} 12^{\prime \prime}$ & $48^{\circ} 02^{\prime} 06^{\prime \prime}$ & $3790 \pm 110$ & $\cong 0$ & Gif-3437 & Suguio et al., 1976 \\
Comprida Island & $24^{\circ} 59^{\prime} 00^{\prime \prime}$ & $47^{\circ} 53^{\prime} 00^{\prime \prime}$ & $4120 \pm 110$ & $<+1.5$ & Gif-3436 & Suguio et al., 1976 \\
Comprida Island & $24^{\circ} 59^{\prime} 00^{\prime \prime}$ & $47^{\circ} 53^{\prime} 00^{\prime \prime}$ & $4120 \pm 90$ & $<+1.5$ & Bah.-303 & Suguio et al., 1976 \\
Tapera-Cananéia & $25^{\circ} 02^{\prime} 00^{\prime \prime}$ & $47^{\circ} 59^{\prime} 00^{\prime \prime}$ & $3960 \pm 90$ & $<+1.5$ & Bah-291 & Martin et al., 1979b \\
\hline
\end{tabular}

W

Prata mountain
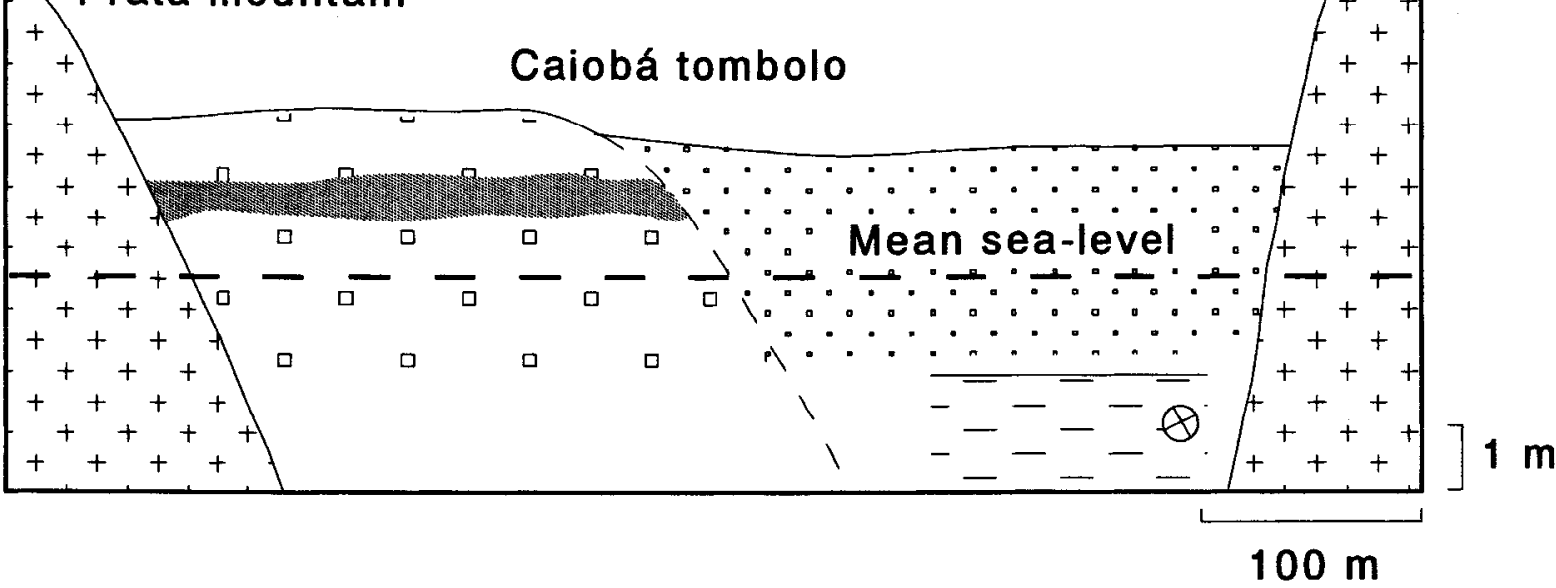

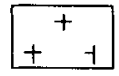

Crystalline rocks

Organic-rich horizon

$\because \because$

Younger sandy sequence

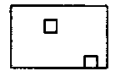

Older sandy sequence

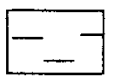

Clayey-silty marine sediments

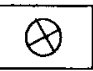

Dated shell sample $(3830 \pm 120$ y.B.P. $)$

Fig. 7. Schematic profile of the Caiobá tombolo and the location of the dated sample.

on the highest elevation of the innermost part of the wave-built Holocene strandplain. These authors defined the Holocene strandplain by the non-occurrence of indurated, epigenetically organic-rich, dark-brown sands, then acknowledged to be a characteristic of Pleistocene deposits only. However, Angulo (1992) and Angulo and Suguio (1995) presented a new set of dated 
Table 2

Radiocarbon datings of sedimentary deposits

\begin{tabular}{|c|c|c|c|c|c|c|c|}
\hline Local & $\begin{array}{l}\text { Latitude } \\
\text { (south) }\end{array}$ & $\begin{array}{l}\text { Longitude } \\
\text { (west) }\end{array}$ & Nature & $\begin{array}{l}\text { Age } \\
\text { (years B.P.) }\end{array}$ & $\begin{array}{l}\text { Palaeo-level } \\
(\mathrm{m})\end{array}$ & Lab. Ref. No. & Source \\
\hline Caiobá Tombolo & $25^{\circ} 50^{\prime} 55^{\prime \prime}$ & $48^{\circ} 32^{\prime} 19^{\prime \prime}$ & shells a & $3830 \pm 120$ & $>0^{\mathrm{c}}$ & SI-327 & Bigarella, 1971 \\
\hline Guaratuba & $25^{\circ} 56^{\prime} 55^{\prime \prime}$ & $48^{\circ} 36^{\prime} 11^{\prime \prime}$ & shells ${ }^{b}$ & $3160 \pm 170$ & $>+1.0$ & Bah-1277 & Martin et al., 1988 \\
\hline Guaratuba & $25^{\circ} 56^{\prime} 55^{\prime \prime}$ & $48^{\circ} 36^{\prime} 11^{\prime \prime}$ & shells ${ }^{b}$ & $2970 \pm 150$ & $>+1.0$ & Bah-1278 & Martin et a1., 1988 \\
\hline Guaraguaçu River & $25^{\circ} 33^{\prime} 14^{\prime \prime}$ & $48^{\circ} 27^{\prime} 48^{\prime \prime}$ & shells ${ }^{b}$ & $2680 \pm 240$ & $+1.0 \pm 0.5^{\mathrm{d}}$ & Bah-1270 & Martin et al., 1988 \\
\hline Itiberê River & $25^{\circ} 32^{\prime} 33^{\prime \prime}$ & $48^{\circ} 31^{\prime} 31^{\prime \prime}$ & shells ${ }^{b}$ & $2650 \pm 170$ & $+1.0 \pm 0.5^{\mathrm{e}}$ & Bah-1269 & Martin et al., 1988 \\
\hline Cananéia & $24^{\circ} 51^{\prime} 54^{\prime \prime}$ & $47^{\circ} 47^{\prime} 12^{\prime \prime}$ & wood & $3780 \pm 110$ & $+2 \pm 0.5$ & Bah-630 & Martin et al., 1979b \\
\hline Cananéia & $24^{\circ} 51^{\prime} 18^{\prime \prime}$ & $47^{\circ} 28^{\prime} 30^{\prime \prime}$ & wood detritus & $3710 \pm 140$ & $+0.5 \pm 0.3$ & Bah-445 & Martin et al., 1979b \\
\hline MelMel's Island & $25^{\circ} 32^{\prime} 20^{\prime \prime}$ & $48^{\circ} 17^{\prime} 26^{\prime \prime}$ & vermetids & $3500 \pm 60$ & $+2.90 \pm 0.50$ & GSC-5255 & Angulo, 1992 \\
\hline MelMel's Island & $25^{\circ} 32^{\prime} 54^{\prime \prime}$ & $48^{\circ} 17^{\prime} 30^{\prime \prime}$ & vermetids & $3300 \pm 60$ & $+2.05 \pm 0.50$ & CENA-143 & Angulo, in prep. \\
\hline Caiobá Hill & $25^{\circ} 51^{\prime} 06^{\prime \prime}$ & $48^{\circ} 32^{\prime} 04^{\prime \prime}$ & vermetids & $4750 \pm 70$ & $+3.60 \pm 0.50$ & CENA- 140 & Angulo, in prep. \\
\hline Caiobá Hill & $25^{\circ} 51^{\prime} 06^{\prime \prime}$ & $48^{\circ} 32^{\prime} 04^{\prime \prime}$ & vermetids & $5300 \pm 70$ & $+3.45 \pm 0.50$ & CENA-141 & Angulo, in prep. \\
\hline
\end{tabular}

${ }^{a}$ Marine shells, Arca and Donax amongst others (J.J. Bigarella, pers. commun.).

${ }^{\mathrm{b}}$ Estuarine, mainly Anomalocardia brasiliana.

c Palaeo-level after Martin et al., $<0 \mathrm{~m}$.

d Palaeo-level after Angulo (1993), $>+0.9 \mathrm{~m}$.

'Palaeo-level after Angulo (1993), > + $1.0 \mathrm{~m}$.

palaeo-sea-level indicators for the area, discovering that the epigenetically organic-rich sands also occur in Holocene deposits, and re-evaluated the morphological boundary between the Pleistocene and Holocene strandplains (Fig. 5). With this information, sea level at the end of the PMT was re-assessed at about $4 \mathrm{~m}$ above the present level (Fig. 8). The overall curve for Paranaguá then attained elevations similar to the other Brazilian coastal sectors (Fig. 2), suggesting that there may not be any significant difference between the maximum Holocene sea levels along the Brazilian coast (Angulo and Suguio, 1995).

Four dated samples of vermetid in the region was presented by Angulo (1992, in prep.), two from the Caiobá tombolo and two from $\mathrm{Mcl}$ Island (Table 2, Fig. 4B). The samples from Caiobá, dated at 5300 years B.P. (CENA 141) and 4750 years B.P. (CENA 140), indicate the approximate maximum palaeo-sea level at the end of the PMT, i.e., $3.45 \mathrm{~m}$ and $3.60 \mathrm{~m}$, respectively. Those from Mel Island dated at 3500 years B.P. (GSC-5255) and 3300 years B.P. (CENA 143), indicate palaeo-sea levels of $2.90 \mathrm{~m}$ and $2.05 \mathrm{~m}$, respectively. All CENA vermetid datings followed standard preparation procedures (such as mechanical cleaning of secondary surface encrustations and chemical treatment for adsorbed material ), and were corrected only for their $\delta^{13} \mathrm{C}$ factor.

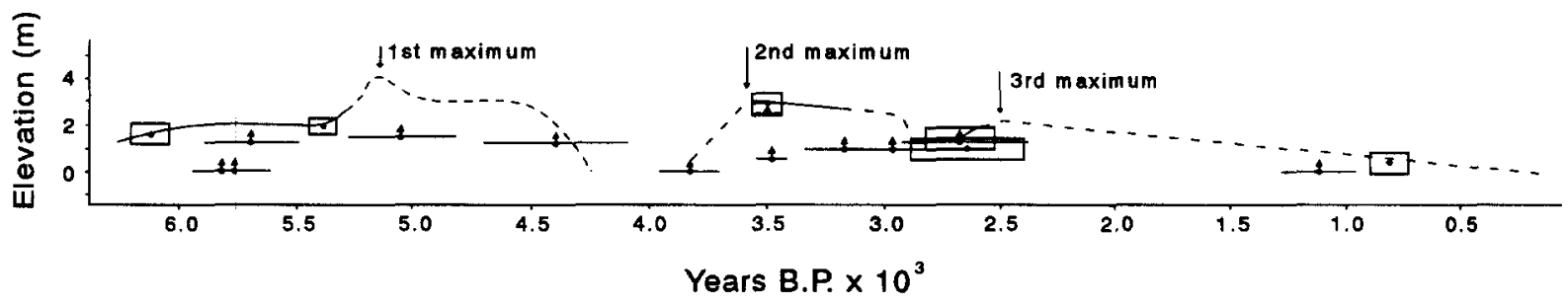

Fig. 8. Sea-level curve for the Paranaguá costal plain (Angulo and Suguio, 1995), re-assessing the position of the sea-level maximum after the PMT. 


\subsection{Cananéia coastal plain}

The Holocene sea-level maximum in Cananéia was assessed through a so-called erosional platform identified on the Pleistocene strandplain at the southern end of Comprida Island (Suguio et al., 1976; Martin and Suguio, 1976) (Fig. 4C). Normally, the Pleistocene strandplain at the same relative position attains $5-6 \mathrm{~m}$ in elevation, whereas in this location it does not surpass 3-4 m. Similar to the scenario drawn in the evolutionary model (Fig. 6), it was hypothesised that no barrier was formed during the Holocene transgression in the area, and that the Pleistocene strandplain was partially eroded at the end of the PMT (Fig. 9). Based on the elevation of the 'eroded' platform, the authors suggested that sea level at the end of the PMT was not higher than $3.5 \mathrm{~m}$.

As in Paranaguá, the only evidence for the secondary oscillations in Cananéia were shellmidden deposits. Suguio et al. (1976) and Martin and Suguio (1976) presented the results of four radiocarbon datings performed on samples from three different shell-middens, dated at 4130 years B.P. (Bah. 289), 4120 and 4120 years B.P. (Gif. 3436 and Bah. 303) and 3790 years B.P. (Gif. 3437). The middens from the Ararapira channel (samples Bah. 289 and Gif. 3437, Fig. 4C), are the only ones described by the authors. Samples Gif. 3436 and Bah. 303, from the same site, are suggested to be related to a palaeo-sea level below $+1.5 \mathrm{~m}$. The midden where sample Gif. 3437 originated has its base at about the present high tide level, and was interpreted as evidence of a sea level close to the present one at about 3800 years B.P. Sample Bah. 289 was taken from the base of another midden situated about $0.5 \mathrm{~m}$ above the present high tide level, and its age appears to substantiate the proposed sea-level oscillation. Martin et al. (1979b) presented the results of another shell-midden sample (Bah. 291), dated at 3960 years B.P. and related it to a palaeo-sea level below $+1.5 \mathrm{~m}$.

Two more datings within the time frame of the secondary sea-level oscillations are presented by Martin et al. (1979b) for the Cananéia region, although without detailed descriptions of the sampling sites. Sample Bah. 630 (Fig. 4C) is a piece of wood dated at 3780 years B.P. and related to a palaeo-sea level of $+2 \mathrm{~m}$. Sample Bah. 445 (Fig. 4C), made of wood detritus, was dated at 3710 years B.P. and related to a palaeo-sea level of $+0.5 \mathrm{~m}$.

\section{Discussion}

\subsection{Wave built terraces and the reconstruction of palaeo-sea levels}

For the whole Brazilian coast there are only five palaeo-sea level indicators (oyster and vermetids) likely to give the elevation of the sea level maximum at the end of the PMT (one in the State of Bahia, one in the State of Rio de Janeiro, one in the State of São Paulo and 2 in the State of Paraná) (Suguio and Martin, 1978a; Martin et al., 1979b; Martin and Suguio, 1978; Angulo, in prep.). Hitherto, in the studied area as well as in any of other previously investigated sites lacking absolute datings, inference of the sea-level maximum was made upon the maximum elevations of wave-built terraces (Fig. 2) (Suguio et al., 1976; Martin and Suguio, 1976; Martin et al., 1988).

The elevations of the terraces are related to the elevations of the swash limits during storms, which in its turn depends on the wave spectrum, beach grain size and slope, and the bathymetry of the nearshore and the tidal range. Roep (1986) investigated the elevation of the swash limit during a storm and during fair weather in the North Sea, showing that palaeo-sea levels in that area should be $2-3 \mathrm{~m}$ below the surface of the wave-built terraces.

Bigarella et al. (1961) studied the elevation of several beaches in the State of Paraná, and verified a direct relationship between the mean grain size of the beach face and the elevation of the backshore in relation to MSL. Although no consideration was given to the energy level of the beaches, Bigarella et al. (1961) found that coarser grain beaches were associated with higher back-shore elevations. For instance, a beach with mean grain size of $0.5 \mathrm{~mm}$ was associated with a back-shore elevation of 3 to $6 \mathrm{~m}$ above MSL, whereas a mean grain size diameter of $0.125 \mathrm{~mm}$ was associated 
A) Maximum of 5100 years B.P.

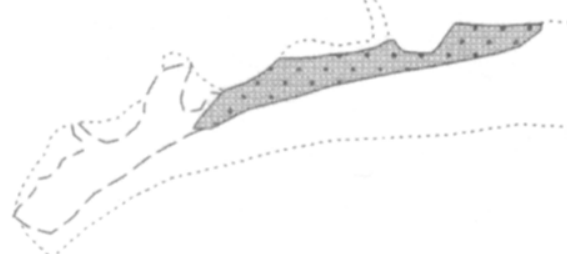

B) Maximum of 3500 years B.P.

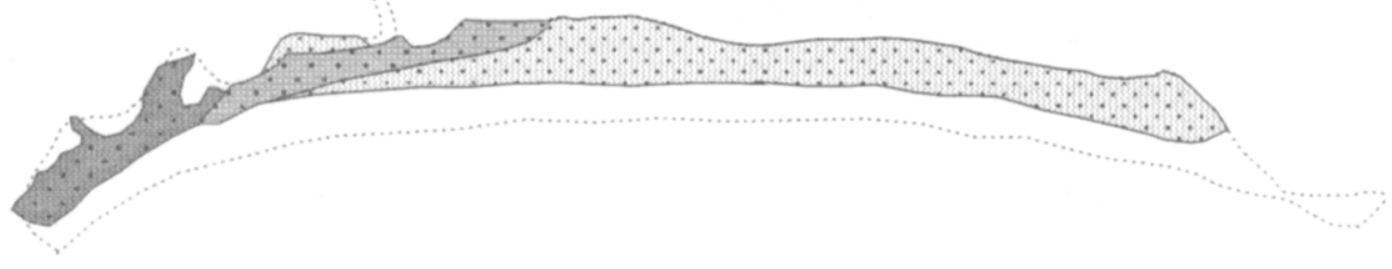

C) Present stage

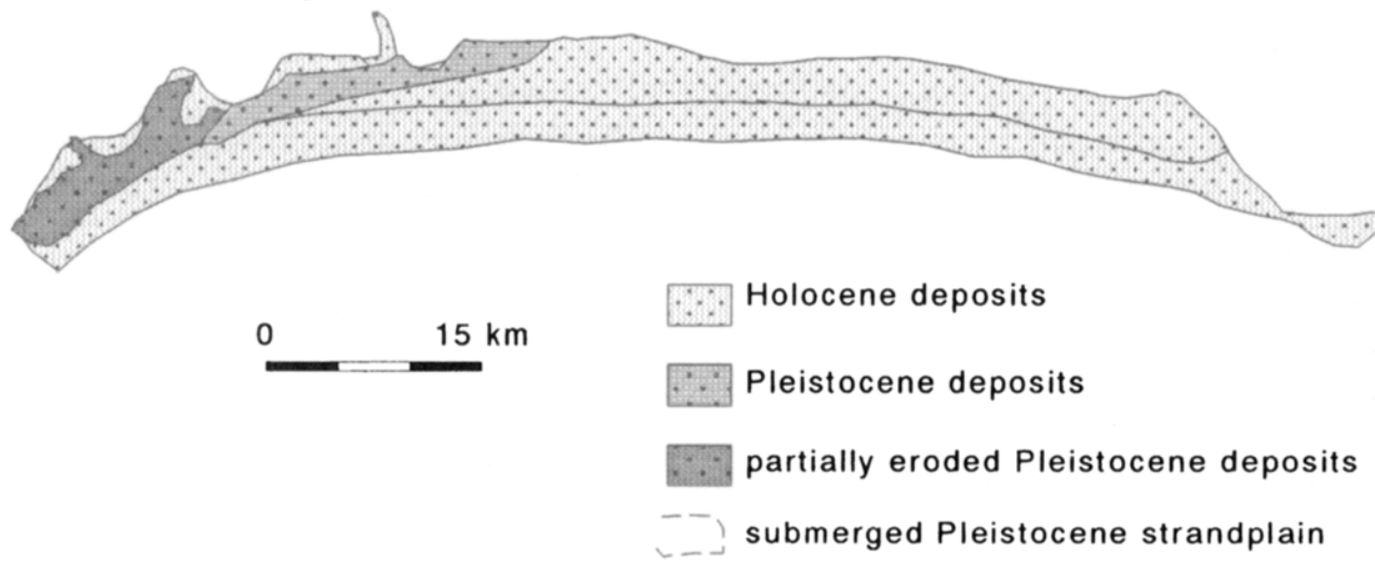

Fig. 9. Morphology and sedimentary units of Comprida Island. (A) The Pleistocene strandplain during the Holocene highstand. (B) The Holocene strandplain and the remnants of the submerged Pleistocene strandplain. (C) The present morphology (Suguio et al., 1976)

with back-shore elevation of 2.5 to $3 \mathrm{~m}$ above MSL. These results show that wave- built terraces with different elevations can be associated with the same MSL. They also indicate that in the State of Paraná, and possibly in the whole study area, MSL at the end of the PMT may have been 1 to $6 \mathrm{~m}$ below the average elevation of the inland-most part of the strandplain (Angulo, 1994).

Suguio et al. (1976) and Martin and Suguio (1976), on the basis of the elevation of a proposed
Holocene strandplain ( $3.5 \mathrm{~m}$ ), suggested that MSL at the end of the PMT was between 3.5 and $4 \mathrm{~m}$ (Fig. 9). According to the model used by these authors (Fig. 6), the beginning of the strandpiain formation is associated with a falling sea level, a mechanism similar to the emergence of an offshore bar (Hoyt, 1967). During the final phases of the transgression, waves eroded the top of the Pleistocene strandplain (Fig. 9), and the Holocene strandplain was formed during the subsequent 
regression. Assuming that the results of Bigarella et al. (1961) also apply to this region (mean grain size around $0.15 \mathrm{~mm}$, Tessler, 1988), the $+3.5 \mathrm{~m}$ elevation of the Holocene strandplain at the end of the PMT would more likely be related to a sea level lower than $+2.5 \mathrm{~m}$ at the end of the PMT, which is apparently too low. We believe that the so-called eroded Pleistocene strandplain platform, close to the estuary entrance, is actually a Holocene strandplain formed after the PMT, associated with a decreasing tidal prism and inlet cross-sectional area. A visit to the area revealed that exposed sections of the seaward strandplain along the Cananéia channel (Fig. 4C) show epigenetically indurated sands, which may have been the reason for the Pleistocene classification proposed by Suguio et al. (1976) and Martin and Suguio (1976), similar to what occurred in the Paranaguá coastal plain.

The samples of vermetid dating at 5300 and 4750 years B.P. (Table 2) show that sea level at the end of the PMT was about $+3.5 \mathrm{~m}$. In the Paranaguá coastal plain we have been gathering an increasing amount of evidence showing that sea level at the end of the PMT was lower than $+4 \mathrm{~m}$. The evidence includes: (1) the seaward and lowest side of the Pleistocene strandplain, with no signs of in-place drowning, is about $4 \mathrm{~m}$ above MSL, which is an indication that the Holocene sea-level maximum could not have been higher than $4 \mathrm{~m}$ (Lessa and Angulo, in prep.); and (2) sedimentary structures observed on exposed cliffs at the back of the Holocene strandplain, along with the maximum elevation of palaeo-beach deposits, indicate that the Holocene sea-level maximum was between 3 and $4 \mathrm{~m}$ (Lessa and Angulo, in prep.). The ages provided by the vermetid samples mentioned above are about 200 and 350 years older, respectively, as judged from the suggested time for the end of the PMT ( 5100 years B.P.). Therefore is possible that sea level may have risen slightly above $+3.5 \mathrm{~m}$, although not surpassing $+4 \mathrm{~m}$.

\subsection{Secondary oscillations and topographic records}

The existence of secondary sea-level oscillations with amplitudes of about $4 \mathrm{~m}$, would have forced significant transgressive and regressive cycles.
Shoreline advance and retreat associated with oscillations of decreasing amplitudes could be in the order of a few kilometres, and would have left records on the coastal landscape.

A transgressive scenario on a barrier coast is commonly associated with lagoons stranded behind newly formed barriers. Hence, two consecutive highstands may leave behind two barriers separated by a lagoon or at least a low-lying, swampy area. In a time when the chronology of the coastal landscape was still uncovered, and in the light of the recently proposed sea-level curves, some Brazilian researchers interpreted the actual Pleistocene barriers/strandplains as the Holocene PMT, and the actual Holocene (PMT) barriers/ strandplains as the one resulting from the proposed transgression at 3500 years B.P. (Martin and Suguio, 1976; Perrin, 1984; Muehe and Ignarra, 1984; Maia et al., 1984; Neto, 1984; Turq et al., 1986; Muehe and Corrêa, 1988). In these cases, the Pleistocene barrier/strandplain was interpreted as completely eroded, buried by the PMT, or even non-existent.

References to Pleistocene barrier/strandplains were only made in studies of the large beach ridge plains associated with river mouths (Dominguez et al., 1981; Martin et al., 1984b; Silva, 1987). Again accepting the occurrence of the secondary sea-level oscillations, these investigations suggest that the 3500 years B.P. transgression would have either left a third barrier generation of strandplains (Dominguez et al., 1981; Martin et al., 1984b) or imprinted discontinuities observed in the beach ridges (Silva, 1987).

With the aim of verifying the morphological adjustment of the shoreface to the effects of a fall and subsequent rise of sea level, a simulation exercise was performed assuming the approximate rate and amplitude of the first proposed oscillation ( 3800 years B.P.). The simulation was carried out using the Shoreface Translation Model (Cowell et al., 1992, 1995; Roy et al., 1995), which involves the translation of a pre-determined barrier form across a substrate under the influence of a falling or rising sea level, while maintaining the shoreface shape. The values for the environmental variables used in the model (wave height, shoreface profile, storm surge height, longshore sediment imbalance, 
and depth at surf base) were those from the coast of the State of Paraná. A longshore sediment imbalance of $+15 \mathrm{~m}^{3} \mathrm{~m}^{-1}$ year ${ }^{-1}$ was assumed based on the coastal progradation rates assessed at Pontal do Sul (Fig. 4) (Soares et al., 1994). The simulation started at 5100 years B.P. with a sea level $5 \mathrm{~m}$ above the present MSL and a barrier $500 \mathrm{~m}$ wide (Fig. 10a). In Fig. 10b sea level fell $2 \mathrm{~m}$ below the present elevation at 3800 years B.P. During this period the barrier became some $9000 \mathrm{~m}$ wider with removal of sediment from the lower shoreface and transportation to the upper shoreface. Subsequently, sea level rose again to $+3 \mathrm{~m}$, and sediments were eroded from the upper shoreface and deposited on the lower shoreface. Additionally, a terrace $2 \mathrm{~km}$ wide was built in the back-shore (Fig. 10c). The next fall of sea level towards the present elevation widened the barrier once more (Fig. 10d).

The simulation shows that the morphological record associated with the secondary oscillations would more likely form a well defined terrace ('encroached barrier', Roy et al., 1995) than a barrier-lagoon system. The width of the terrace is heavily dependent on the longshore sediment imbalance; a simulation with no sediment imbalance resulted in the same topography but with a terrace $500 \mathrm{~m}$ wide. It is suggested that the morphological change observed in the simulation would be characteristic of most of the Brazilian barrier coasts. The existence of particular topographic features at strandplains associated with large river mouths, can be explained by lateral spit growth or even the emergence of swash bars downdrift of the river outlet (Dias, 1981). Both processes can account for many isolated inland depressions characteristic of these wave-dominated river mouths. In regard to the interruption of beach ridge formation, this could easily be explained by fluctuations in the sediment supply associated with the dynamics of the river mouths.

\subsection{The secondary oscillations and palaeo-sea level indicators}

With the exception of one natural shell deposit found in the Caiobá tombolo and two other samples of wood and wood detritus from Cananéia
(Table 2), where diverging interpretations exist, all the evidence supporting secondary sea-level oscillations in the study area comes from the dating of shell-middens.

The age ( 3830 years B.P.) and genera (Donax and Arca) of the shells from the Caiobá tombolo, when used with the sea-level curve of Fairbridge (1962), led Bigarella (1971) to conclude that the shells were deposited above the present sea level. However, Bigarella (1971) did not suggest the depositional environment, nor determined whether the shells were transported or found in living position, and failed to propose the generating mechanism of the observed sedimentary succession to strengthen his assertion. In light of the transgressive nature of the sedimentary sequence, where muds underlie marine sand, Martin et al. (1988) interpreted the age and the nature of the deposit as evidence of a sea level lower than the present sea level. The interpretation of Bigarella (1971) seems unreasonable as it is difficult to envisage the deposition of mud at the mouth of a wave-dominated estuary. The present surface sediment distribution at the mouth of the estuary shows the deposition of medium to coarse sands in most of the area, as indicated by the presence of large-scale bedforms observed on vertical aerial photographs. The interpretation of Martin et al. (1988) is more reasonable, given the sequence of the sedimentary strata. Nevertheless, as has been shown in the simulation exercise above, the formation of a transgressive sequence including a backbarrier lagoon is unlikely. We interpret the stratigraphic profile as resulting from the transgression that occurred until 5100 years B.P., and the subsequent regression. The transgression caused the translocation of the barrier coastline over palaeolagoonal/estuarine deposits (mud sequence) that became exposed to erosion on the shoreface towards the end of the PMT. The subsequent sealevel fall promoted the progradation of the coastline and the burying of the mud by a thin layer of sand. Hence, the shells could indicate the approximate time when the layer became buried. Presently, a patch of similar mud deposit is found parallel to the shoreline beneath a couple of centimetres of sand, at a depth similar $(-2 \mathrm{~m})$ to the mud found 

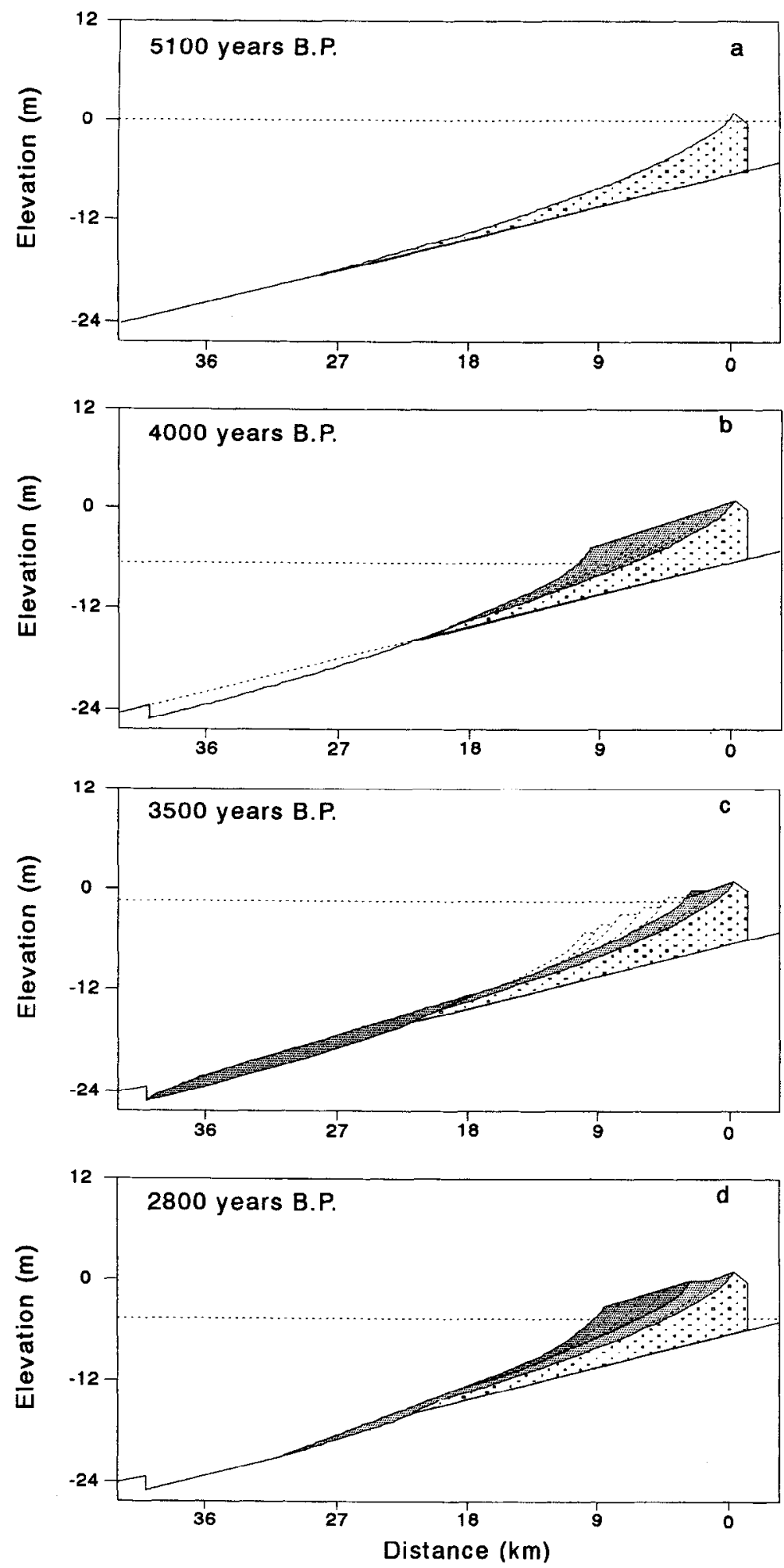

Fig. 10. A simulation of the two-dimensional morphological changes of the Holocene barrier in the Paranaguá coastal plain considering one secondary oscillation after the end of the PMT. 
in the tombolo (C.R. Soares and C. Borzone, pers. commun., 1995).

It is difficult to discuss samples Bah. 630 and Bah. 445 (Table 2) because there is no information about the sampling site or any indication on how the palaeo-sea level was estimated. However, it is worth noting that sample Bah. 630 gives a palaeolevel of $+2 \mathrm{~m}$ at the time of a proposed secondary oscillation.

The two datings ( 3160 years B.P. and 2970 years B.P.; Bah-1277 and Bah-1278) derived from samples of mollusc shells (mostly Anomalocardia brasiliana) presented by Martin et al. (1988) indicate a sea level about $1 \mathrm{~m}$ above the present (Angulo, 1993). Again, these samples indicate sea levels higher than those expected around the secondary oscillation (3000-2700 years B.P.).

\subsection{The shell-midden data}

As shown in Table 1, the majority of the data supporting the secondary sea-level oscillations come from shell-midden deposits. Two types of problems were met during the re-evaluation of the shell-midden data as palaeo-sea level indicators. The first problem occurs in the interpretation of the elevation of the base of the shell-midden. The second problem results from the conflicts between shell-midden data and other indicators, or even within the shell-midden data.

Misinterpretation of the actual elevation of the base of the middens was, at least in one case, due to slumping over erosive channel margins. Sample Gif. 3437 from Cananéia was interpreted by Suguio et al. (1976) as an indication of a sea level not higher than the present one at 3790 years B.P. The sample was collected from the base of the shell-midden, and interpreted to be at the same elevation as the present high tide level. A field inspection of that site revealed that part of the midden has slumped over the edge of the channel. The base of the deposit is actually sitting on top of a palaeo-lagoonal terrace, approximately $1.5 \mathrm{~m}$ above the mean spring high tide level. In another instance, Martin et al. (1988) misinterpreted the maximum tidal elevation, under-estimating the palaeo-sea level by more than $1 \mathrm{~m}$ (Angulo and Suguio, 1995).
A couple of cases exist regarding conflicting shell-midden data. Martin et al. (1988), in the analysis of the Rosas' Island shell-midden, corroborates the interpretation of Laming-Emperaire (1968) by stating that sea level was rising at 3100 years B.P. This interpretation contrasts with the proposed curves (Martin and Suguio, 1976; Suguio et al., 1985), at both local and regional scales, because it would mean some 500 years delay in the proposed transgression between 3800 and 3500 years B.P. It is difficult to imagine a significant sea-level rise in Paranaguá concomitant with a sealevel fall in Cananéia or Itajaí (Fig. 1), just a few hundred kilometres away. Moreover, there are some dated samples from the same region that indicate sea levels higher than at present: (1) two samples of mollusc shells, Bah-1269 and Bah-1270 (Table 2), point to a sea level $1 \mathrm{~m}$ higher relative to the present elevation al 2680 years B.P. and 2650 years B.P., respectively; (2) two vermetid samples dated by Angulo (1992, in prep.), show that sea level was $2.90 \mathrm{~m}$ and $2.05 \mathrm{~m}$ above the present elevation at 3500 and 3300 years B.P., respectively (Table 1 ), suggesting that sea level would already have attained a highstand and would be falling before 3100 years B.P.

A sample collected in the lower portion of a shell-midden in Boguaçu River (the Guaratuba coastal plain) (Fig. 4A) was dated at 3290 (Bah. 1273) (Martin et al., 1988). The midden was located on top of a palaeo-lagoonal surface elevated $1.3 \mathrm{~m}$ above the present MSL. This was used by Martin et al. (1988) as an indication that the sea-level maxima after the supposed transgression between 3800 and 3500 was not higher than $1.3 \mathrm{~m}$. Vermetid data from the area (Table 2) show that at 3500 and 3300 years B.P., sea level was at 2.90 and $2.05 \mathrm{~m}$ above the present MSL, respectively (Table 2).

These inconsistencies call attention to the danger of the utilization of shell-middens as palaeo-sealevel indicators. Most of the middens considered here were built on top of palaeo-lagoonal deposits, which are likely to suffer subsidence due to compaction and dewatering. Therefore, it is possible that the present surfaces are lower than the original ones (Martin et al., 1986; Dominguez et al., 1990). Moreover, there is no supporting evidence to the 


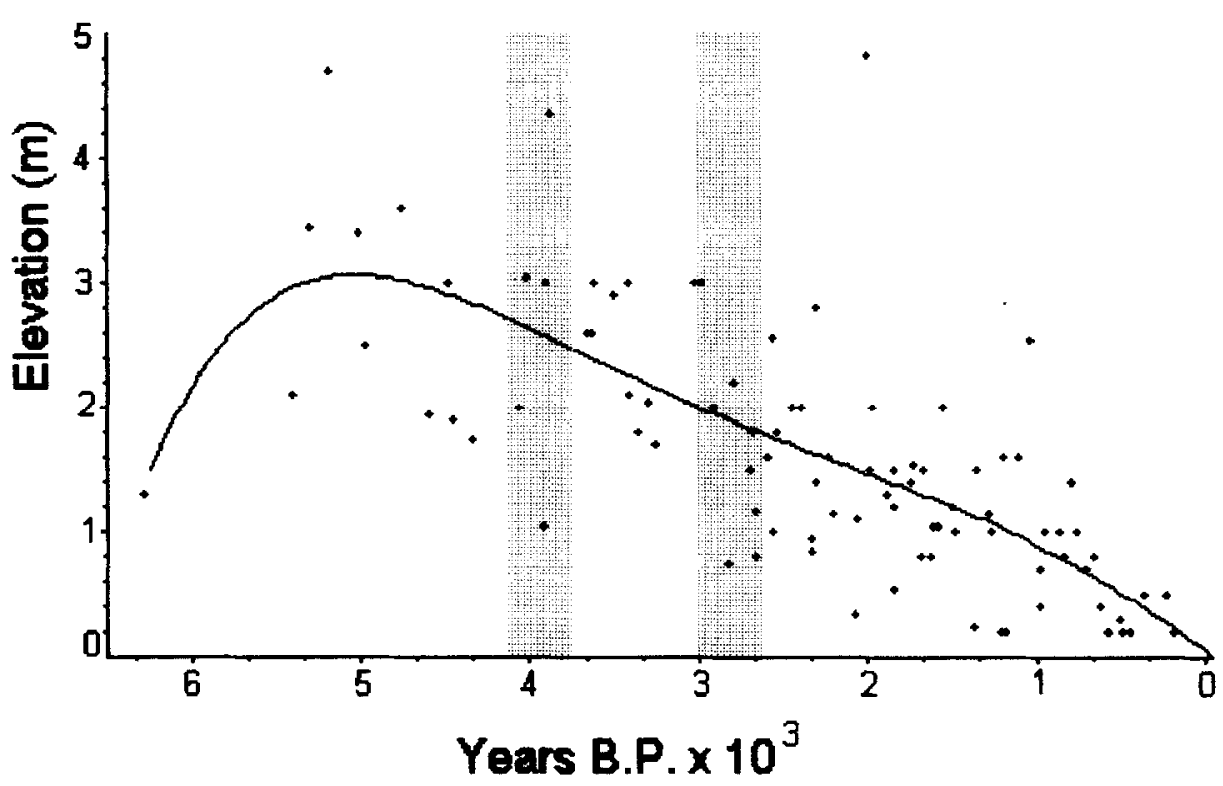

Fig. 11. Elevation of the published palaeo-sea-level indicators in Brazil derived from vermetid radiocarbon dates (see Table 3). Shaded areas indicate the time for the proposed secondary oscillations and the line is a 4 th-order polynomial best fit.

fact that the shell-middens were always built above the high tide level; only the fact that it appears to be logical from our viewpoint is not enough to dispute the various possibilities that could have led an unknown culture to initiate a mound under water. Therefore, this criterion can not be regarded as a reliable evidence for palaeo-sea levels.

\section{Is there a common Brazilian sea-level curve?}

Despite the noise that local tectonic behaviour may impinge on the palaeo-sea-level records of any site, as in Salvador (Martin et al., 1984a), there appear to be few differences between the proposed Brazilian sea-level curves. Of primary importance, however, is the suggested rise in the elevation attained by sea level northward along the Brazilian coast at the end of the PMT (Martin et al., 1985). In Cananéia and Paranaguá, the sea level reached altitudes between $+3.5 \mathrm{~m}$ and $+4 \mathrm{~m}$ (this paper), while it may have attained $+4 \mathrm{~m}$ to $+5 \mathrm{~m}$ in Salvador and Angra dos Reis (Martin et al., 1979a,b; Martin and Suguio, 1989) (Fig. 2a,d), as given by absolute datings. With the information available at present, it seems possible that a single curve could represent the trend of the eustatic oscillation along the Brazilian coast with an error of $\pm 1.0 \mathrm{~m}$. Indeed, the secondary oscillations discussed in this paper were proposed to occur at the same time throughout the coast (Suguio et al., 1985). Therefore, the available palaeo-sea level data may cluster along the mean of the proposed eustatic oscillations.

Nevertheless, there are many problems with the certainty of the dated indicators that come from the natural sedimentary deposits (the majority of them), which may indicate erroneous elevation relative to sea level during deposition. Except for problems involving carbonate recrystallization, the vermetids are widely recognized as an accurate palaeo-sea-level indicator (van Andel and Laborel, 1964; Delibrias and Laborel, 1969; I aborel, 1979, 1986; Angulo, 1993). These organisms occur in the lower quarter of the intertidal area, between neap and spring low tides, and can provide mean sea levels with a precision of 0.1 and $1.0 \mathrm{~m}$, in the best (low tide range and wave height) and worst (high tide range and wave height) scenarios, respectively (Laborel, 1986).

Fig. 11 plots the published vermetid dates along the Brazilian coast (Table 3 ). The data cover the 
Table 3

Datings from vermetid samples published in Brazil

\begin{tabular}{|c|c|c|c|c|c|c|}
\hline Local & $\begin{array}{l}\text { Latitude } \\
\text { (south) }\end{array}$ & $\begin{array}{l}\text { Longitude } \\
\text { (west) }\end{array}$ & $\begin{array}{l}\text { Age } \\
\text { (years B.P.) }\end{array}$ & $\begin{array}{l}\text { Palaeo-level } \\
\text { (m) }\end{array}$ & Lab. Ref. No & Source \\
\hline Ponta de Itapiruba (SC) & $28^{\circ} 20^{\prime} 18^{\prime \prime}$ & $48^{\circ} 41^{\prime} 57^{\prime \prime}$ & $190 \pm 65$ & $+0.20 \pm 0.5$ & CENA-184 & Angulo et al., in prep. \\
\hline Mosuaba $(\mathrm{RJ})$ & $23^{\circ} 01^{\prime} 00^{\prime \prime}$ & $44^{\circ} 13^{\prime} 18^{\prime \prime}$ & $230 \pm 60$ & $+0.50 \pm 0.40$ & Bah-483 & Martin and Suguio, 1978 \\
\hline Rio Vermelho (BA) & $13^{\circ} 00^{\prime} 32^{\prime \prime}$ & $38^{\circ} 30^{\prime} 10^{\prime \prime}$ & $365 \pm 115$ & $+0.50 \pm 0.50$ & Bah-507 & Martin et al., $1979 \mathrm{a}$ \\
\hline Ilha Grande $(\mathbf{R J})$ & $23^{\circ} 10^{\prime} ?$ & $44^{\circ} 10^{\prime \prime} ?$ & $380 \pm 90$ & $+0.50 \pm 0.50$ & Gif-1061 & Delibrias and Laborel, 1969 \\
\hline Ponta de Itapiruba 1 (SC) & $28^{\circ} 20^{\prime} 18^{\prime \prime}$ & $48^{\circ} 41^{\prime} 57^{\prime \prime}$ & $450 \pm 65$ & $+0.20 \pm 0.50$ & CENA-181 & Angulo et al., in prep. \\
\hline Ilha dos Currais (PR) & $25^{\circ} 44^{\prime} 07^{\prime \prime}$ & $48^{\circ} 21^{\prime} 51^{\prime \prime}$ & $490 \pm 60$ & $+0.20 \pm 0.50$ & CENA-137 & Angulo, in prep. \\
\hline Morro da Tapera (SP) & $25^{\circ} 11^{\prime} 36^{\prime \prime}$ & $47^{\circ} 58^{\prime} 18^{\prime \prime}$ & $500 \pm 60$ & $+0.30 \pm 0.50$ & CENA-136 & Angulo, in prep. \\
\hline Ponta de Itapituba 5 (SC) & $28^{\circ} 20^{\prime} 18^{\prime \prime}$ & $48^{\circ} 41^{\prime} 57^{\prime \prime}$ & $570 \pm 65$ & $+0.20 \pm 0.50$ & CENA-185 & Angulo et al., in prep. \\
\hline Picinguaba (SP) & $23^{\circ} 22^{\prime} 36^{\prime \prime}$ & $45^{\circ} 50^{\prime} 24^{\prime \prime}$ & $620 \pm 120$ & $+0.40 \pm 0.40$ & Bah-487 & Martin and Suguio, 1978 \\
\hline Amaralina (BA) & $13^{\circ} 00^{\prime} 32^{\prime \prime}$ & $38^{\circ} 28^{\prime} 04^{\prime \prime}$ & $660 \pm 80$ & $+0.80 \pm 0.50$ & Bah-595 & Martin et al., $1979 a$ \\
\hline Rio Vermelho (BA) & $13^{\circ} 00^{\prime} 32^{\prime \prime}$ & $38^{\circ} 30^{\prime} 00^{\prime \prime}$ & $700 \pm 110$ & $+0.70 \pm 0.50$ & Bah-509 & Martin et al., 1979a \\
\hline Porto da Barra (BA) & $12^{\circ} 59^{\prime} 48^{\prime \prime}$ & $38^{\circ} 31^{\prime} 48^{\prime \prime}$ & $770 \pm 125$ & $+1.00 \pm 0.50$ & Bah-570 & Martin et al., $1979 \mathrm{a}$ \\
\hline Praia de Pernambuco (SP) & $23^{\circ} 58^{\prime} 24^{\prime \prime}$ & $46^{\circ} 11^{\prime} 18^{\prime \prime}$ & $790 \pm 90$ & $+1.40 \pm 0.40$ & Gif-3848 & Suguio and Martin, 1978a \\
\hline 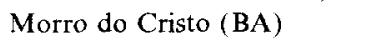 & $14^{\circ} 48^{\prime} 30^{\prime \prime}$ & $39^{\circ} 01^{\prime} 31^{\prime \prime}$ & $830 \pm 90$ & $+0.80 \pm 0.50$ & Bah-574 & Martin et al., 1979a \\
\hline Ponta de Martins de Sá (SP) & $23^{\circ} 37^{\prime} 54^{\prime \prime}$ & $45^{\circ} 23^{\prime} 24^{\prime \prime}$ & $865 \pm 90$ & $+1.00 \pm 0.40$ & Bah-463 & Martin et al., 1979b \\
\hline Porto da Barra (BA) & $12^{\circ} 59^{\prime} 48^{\prime \prime}$ & $38^{\circ} 31^{\prime} 48^{\prime \prime}$ & $950 \pm 125$ & $+1.00 \pm 0.50$ & $1-569$ & Martin et al., $1979 \mathrm{a}$ \\
\hline Tarituba ( RJ) & & $44^{\circ} 36^{\prime} 42^{\prime \prime}$ & $975 \pm 80$ & $+0.70 \pm 0.40$ & $1-478$ & Martin and Suguio, 1978 \\
\hline Ponta do Ji 2 (SC) & $28^{\circ} 25^{\prime} 25^{\prime \prime}$ & $48^{\circ} 44^{\prime}$ & $980 \pm 65$ & & & Angulo et al., in prep. \\
\hline Praia de Armação (SC) & & 4836 & $1045 \pm 75$ & $+2.55 \pm 0.50$ & GX-14061 & Angulo, 1989 \\
\hline Poço de Anchieta (SP) & $24^{\circ} 12^{\prime} 00^{\prime \prime}$ & $46^{\circ} 48^{\prime}$ & $1105 \pm 115$ & & & Suguio and Martin, 1978a \\
\hline Cabo de Santa Marta (SC) & $28^{\circ} 36^{\prime} 18^{\prime \prime}$ & $48^{\circ} 48^{\prime} 54^{\prime \prime}$ & $1180 \pm 70$ & $+0.20 \pm 0.50$ & CENA-173 & Angulo et al., in prep. \\
\hline Cabo San Agostinho (PE) & $08^{\circ} 20^{\prime} 12^{\prime \prime}$ & $34^{\circ} 56^{\prime} 00^{\prime \prime}$ & $1190 \pm 130$ & $.60 \pm 0.50$ & Shell-A17 & van Andel and Lahorel, 1964 \\
\hline Passagem 3 (SC) & $28^{\circ} 30^{\prime} 19^{\prime \prime}$ & $48^{\circ} 44^{\prime} 45^{\prime \prime}$ & $1200 \pm 70$ & $+0.20 \pm 0.50$ & CENA-194 & Angulo et al., in prep. \\
\hline Ponta da Ilhota 1 (SC) & $28^{\circ} 32^{\prime} 10^{\prime \prime}$ & $48^{\circ} 45^{\prime} 36^{\prime \prime}$ & $1210 \pm 70$ & $+0.20 \pm 0.50$ & CENA-186 & Angulo et al., in prep. \\
\hline Morro da Enseada (SP) & $23^{\prime} 49^{\prime} 12^{\prime \prime}$ & $46^{\circ} 02^{\prime} 12^{\prime \prime}$ & $1270 \pm 130$ & $+1.00 \pm 0.40$ & Bah-356 & Suguio and Martin, 1978a \\
\hline Ilha dos Currais (PR) & $25^{\circ} 44^{\prime} 07^{\prime \prime}$ & $48^{\circ} 21^{\prime} 51^{\prime \prime}$ & $1280 \pm 60$ & $+1.15 \pm 0.50$ & CENA-138 & Angulo, in prep. \\
\hline Rio Vermelho (BA) & $3^{\circ} 00^{\prime} 32^{\prime \prime}$ & $38^{\circ} 30^{\prime} 00^{\prime \prime}$ & $1360 \pm 120$ & $+1.50 \pm 0.50$ & Bah-588 & Martin et al., 1979a \\
\hline Cabo de Santa Marta 7 (SC) & $28^{\circ} 36^{\prime} 18^{\prime \prime}$ & $48^{\circ} 48^{\prime} 54^{\prime \prime}$ & $1370 \pm 60$ & $+0.25 \pm 0.50$ & CENA-175 & Angulo et al., in prep. \\
\hline Parati-Mirim (RJ) & & $44^{\circ} 37^{\prime} 36^{\prime \prime}$ & $1490 \pm 80$ & $+1.00 \pm 0.40$ & Bah-482 & Martin and Suguio, 1978 \\
\hline Amaralina (BA) & $13^{\circ} 00^{\prime} 32^{\prime \prime}$ & $38^{\circ} 28^{\prime} 04^{\prime \prime}$ & $1495+140$ & $+1.20+0.50$ & Bah-597 & Martin et al., 1979a \\
\hline Morro do Cristo (BA) & $14^{\circ} 48^{\prime} 30^{\prime \prime}$ & $39^{\circ} 01^{\prime} 31^{\prime \prime}$ & $1560 \pm 80$ & $<+2$ & Bah-573 & Martin et al., 1979a \\
\hline Ponta da Ilhota 2 (SC) & $28^{\circ} 32^{\prime} 10^{\prime \prime}$ & $48^{\circ} 45^{\prime} 36^{\prime \prime}$ & $1580 \pm 70$ & $+1.05 \pm 0.50$ & CENA-187 & Angulo et al., in prep. \\
\hline Cabo de Santa Marta 1 (SC) & $28^{\circ} 36^{\prime} 8^{\prime \prime}$ & $48^{\circ} 48^{\prime} 54^{\prime \prime}$ & $1610 \pm 110$ & $+1.05 \pm 0.50$ & CENA-169 & Angulo et al., in prep. \\
\hline Mangaratiba (RJ) & $22^{\circ} 58^{\prime} 12^{\prime \prime}$ & $44^{\circ} 02^{\prime} 48^{\prime \prime}$ & $1630 \pm 65$ & $+0.80 \pm 0.40$ & Bah-499 & Martin and Suguio, 1978 \\
\hline Ilha Grande (RJ) & & & $1670 \pm 100$ & $+1.50 \pm 0.50$ & Gif-1060 & Delibrias and Laborel, 1969 \\
\hline Ponta da Galheta I (SC) & $28^{\circ} 34^{\prime} 00^{\prime \prime}$ & $48^{\circ} 47^{\prime} 11^{\prime \prime}$ & $1690 \pm 90$ & $+0.80 \pm 0.50$ & CENA- 176 & Angulo et al., in prep. \\
\hline Cabo de Santa Marta 4 (SC) & $28^{\circ} 36^{\prime} 18^{\prime \prime}$ & $48^{\circ} 48^{\prime} 54^{\prime \prime}$ & $1730 \pm 70$ & $+1.55 \pm 0.50$ & CENA- 172 & Angulo et al., in prep. \\
\hline Cabo San Agostinho (PE) & $08^{\circ} 20^{\prime} 12^{\prime \prime}$ & $34^{\circ} 56^{\prime} 00^{\prime \prime}$ & $1750 \pm 170$ & $+1.40 \pm 0.50$ & Shell-A21 & van Andel and Laborel, 1964 \\
\hline Ponta do Ji 1 (SC) & $28^{\circ} 25^{\prime} 25^{\prime \prime}$ & $48^{\circ} 44^{\prime} 15^{\prime \prime}$ & $1840 \pm 100$ & $+0.55 \pm 0.50$ & CENA-189 & Angulo et al., in prep. \\
\hline Praia de Mambucaba (RJ) & $23^{\circ} 02^{\prime} 12^{\prime \prime}$ & $44^{\circ} 33^{\prime} 12^{\prime \prime}$ & $1840 \pm 90$ & +1.50 & Bah-471 & Martin and Suguio, 1978 \\
\hline Baía da Fortaleza (SP) & $23^{\circ} 30^{\prime} 00^{\prime \prime}$ & $45^{\circ} 08^{\prime} 30^{\prime \prime}$ & $1840 \pm 120$ & $+1.20 \pm 0.40$ & Bah-468 & Suguio and Martin, 1978a \\
\hline Morro da Tapera (SP) & $25^{\circ} 11^{\prime} 36^{\prime \prime}$ & $47^{\circ} 58^{\prime} 18^{\prime \prime}$ & $1890 \pm 60$ & $+1.30 \pm 0.50$ & CENA-135 & Angulo, in prep. \\
\hline Rio Vermelho (BA) & $13^{\circ} 00^{\prime} 32^{\prime \prime}$ & $30^{\circ} 30^{\prime} 00^{\prime \prime}$ & $1975 \pm 80$ & $+2.00 \pm 0.50$ & Bah-506 & Martin et al., 1979a \\
\hline Morro da Juréia (SP) & $23^{\circ} 45^{\prime} 54^{\prime \prime}$ & $45^{\circ} 48^{\prime} 06^{\prime \prime}$ & $1985 \pm 120$ & $+1.50 \pm 0.40$ & Bah-358 & Suguio and Martin, 1978a \\
\hline Cabo Santo Agostinho (PE) & $08^{\circ} 20^{\prime} 12^{\prime \prime}$ & $34^{\circ} 56^{\prime} 00^{\prime \prime}$ & $2010 \pm 160$ & $+4.83 \pm 0.50$ & Bah-1236 & Dominguez et al., 1990 \\
\hline Ponta da Ilhota 3 (SC) & $28^{\circ} 2^{\prime} 0^{\prime \prime}$ & $48^{\circ} 45^{\prime} 36^{\prime \prime}$ & $2060 \pm 70$ & $+1.10 \pm 0.50$ & CENA-188 & Angulo et al., in prep. \\
\hline Cabo de Santa Marta 6 (SC) & $28^{\circ} 36^{\prime} 18^{\prime \prime}$ & $48^{\circ} 48^{\prime} 54^{\prime \prime}$ & $2080 \pm 60$ & $+0.35 \pm 0.50$ & CENA-174 & Angulo et al., in prep. \\
\hline Ponta da Galheta 2 (SC) & $28^{\circ} 34^{\prime} 00^{\prime \prime}$ & & $2210 \pm 70$ & $+1.15 \pm 0.50$ & CENA-177 & Angulo et al., in prep. \\
\hline Morro São Lourenço (SP) & $23^{\circ} 47^{\prime} 48^{\prime \prime}$ & $45^{\circ} 59^{\prime} 42^{\prime \prime}$ & $2240 \pm 90$ & $+1.60 \pm 0.40$ & Bah-357 & Suguio and Martin, 1978a \\
\hline Ilha do Araújo ( $\mathrm{RJ}$ ) & $23^{\circ} 09^{\prime} 12^{\prime \prime}$ & $44^{\circ} 41^{\prime} 48^{\prime \prime}$ & $2300 \pm 85$ & & Bah-470 & Martin and Suguio, 1978 \\
\hline Rio Vermelho (BA) & $13^{\circ} 00^{\prime} 32^{\prime \prime}$ & $38^{\circ} 30^{\prime} 00^{\prime \prime}$ & $2310 \pm 115$ & $+2.80 \pm 0.50$ & Bah-508 & Martin et al., $1979 \mathrm{a}$ \\
\hline
\end{tabular}


Table 3 (continued)

\begin{tabular}{|c|c|c|c|c|c|c|}
\hline Local & $\begin{array}{l}\text { Latitude } \\
\text { (south) }\end{array}$ & $\begin{array}{l}\text { Longitude } \\
\text { (west) }\end{array}$ & $\begin{array}{l}\text { Age } \\
\text { (years B.P.) }\end{array}$ & $\begin{array}{l}\text { Palaeo-level } \\
\text { (m) }\end{array}$ & Lab. Ref. No & Source \\
\hline Cabo de Santa Marta 2 (SC) & $28^{\circ} 36^{\prime} 18^{\prime \prime}$ & $48^{\circ} 48^{\prime} 54^{\prime \prime}$ & $2340 \pm 520$ & $+0.85 \pm 0.50$ & CENA-170 & Angulo et al., in prep. \\
\hline Cabo de Santa Marta 3 (SC) & $28^{\circ} 36^{\prime} 18^{\prime \prime}$ & $48^{\circ} 48^{\prime} 54^{\prime \prime}$ & $2340 \pm 80$ & $+0.95 \pm 0.50$ & CENA-171 & Angulo et al., in prep. \\
\hline Cabo Frio (RJ) & $22^{\circ} 54^{\prime} 16^{\prime \prime}$ & $42^{\circ} 00^{\prime} 00^{\prime \prime}$ & $2400 \pm 95$ & $+2.00 \pm 0.50$ & Gif-1935 & Delibrias and Laborel, 1969 \\
\hline Itaparica $(\mathrm{ES})$ & $20^{\circ} 22^{\prime} 49^{\prime \prime}$ & $41^{\circ} 41^{\prime} 51^{\prime \prime}$ & $2450 \pm 95$ & $+2.00 \pm 0.50$ & Gif-1933 & Delibrias and Laborel, 1969 \\
\hline Praia da Enseada (SP) & $23^{\circ} 29^{\prime} 36^{\prime \prime}$ & $45^{\circ} 05^{\prime} 54^{\prime \prime}$ & $2530 \pm 130$ & $+1.80 \pm 0.40$ & Bah-469 & Suguio and Martin, 1978a \\
\hline Passagem 2 (SC) & $28^{\circ} 30^{\prime} 9^{\prime \prime}$ & $48^{\circ} 44^{\prime} 45^{\prime \prime}$ & $2570 \pm 70$ & $+1.00 \pm 0.50$ & CENA-193 & Angulo et al., in prep. \\
\hline Gaibú (PE) & $08^{\circ} 19^{\prime} 05^{\prime \prime}$ & $34^{\circ} 56^{\prime} 43^{\prime \prime}$ & $2570 \perp 160$ & $+2.56 \perp 0.50$ & Bah-1237 & Dominguez et al., 1990 \\
\hline Coroa Grande $(\mathrm{RJ})$ & $22^{\circ} 55^{\prime} 42^{\prime \prime}$ & $43^{\circ} 50^{\prime} 36^{\prime \prime}$ & $2595 \pm 132$ & $+1.60 \pm 0.40$ & Bah-473 & Martin and Suguio, 1978 \\
\hline Ponta Azeda, Ilhabela- (SP) & $23^{\circ} 44^{\prime} 54^{\prime \prime}$ & $45^{\circ} 20^{\prime} 48^{\prime \prime}$ & $2665 \pm 130$ & $+0.80 \pm 0.40$ & Bah-460 & Suguio and Martin, 1978a \\
\hline Gaibú (PE) & $08^{\circ} 19^{\prime} 05^{\prime \prime}$ & $34^{\circ} 56^{\prime} 43^{\prime \prime}$ & $2670 \pm 170$ & $+1.16 \pm 0.50$ & Bah-1222 & Dominguez et al., 1990 \\
\hline Arraial do Cabo (RJ) & $22^{\circ} 56^{\prime} 42^{\prime \prime}$ & $42^{\circ} 01^{\prime} 12^{\prime \prime}$ & $2680 \pm 180$ & $+1.80 \pm 0.40$ & Bah-1298 & Martin and Suguio, 1989 \\
\hline Frade (RJ) & $22^{\circ} 58^{\prime} 42^{\prime \prime}$ & $44^{\circ} 26^{\prime} 18^{\prime \prime}$ & $2695 \pm 130$ & $+1.50 \pm 0.40$ & Bah-465 & Martin and Suguio, 1978 \\
\hline Cabo San Agostinho (PE) & $08^{\circ} 20^{\prime} 12^{\prime \prime}$ & $34^{\circ} 56^{\prime} 00^{\prime \prime}$ & $2790 \pm 150$ & $+2.20 \pm 0.50$ & Shell-A16 & van Andel and Laborel, 1964 \\
\hline Ponta da Galheta 3 (SC) & $28^{\circ} 34^{\prime} 0^{\prime \prime}$ & $48^{\circ} 47^{\prime} 11^{\prime \prime}$ & $2820 \pm 70$ & $+0.75 \pm 0.50$ & CENA-178 & Angulo et al., in prep. \\
\hline Ponta da Galheta 5 (SC) & $28^{\circ} 34^{\prime} 00^{\prime \prime}$ & $48^{\circ} 47^{\prime} 11^{\prime \prime}$ & $2910 \pm 70$ & $+2.00 \pm 0.50$ & CENA-180 & Angulo et al., in prep. \\
\hline Pedra Oca (BA) & & & $3030 \pm 120$ & $>3$ & Bah-542 & Bittencourt et al., 1979 \\
\hline Porto da Barra (BA) & $12^{\circ} 59^{\prime} 48^{\prime \prime}$ & $38^{\circ} 31^{\prime} 48$ & $2990 \pm 135$ & $+3.00 \pm 0.50$ & Bah-568 & Martin et al., 1979a \\
\hline Mangaratiba (RJ) & $22^{\circ} 57^{\prime} 48^{\prime \prime}$ & $44^{\circ} 02^{\prime} 36^{\prime \prime}$ & $3255 \pm 100$ & $+1.70 \pm 0.40$ & Bah-472 & Martin and Suguio, 1978 \\
\hline Ilha do $\mathrm{Mel}(\mathrm{PR})$ & $25^{\circ} 32^{\prime} 54^{\prime \prime}$ & $48^{\circ} 17^{\prime} 30^{\prime \prime}$ & $3300 \pm 60$ & $+2.05 \pm 0.50$ & CENA-143 & Angulo, in prep. \\
\hline Buzios (RJ) & $22^{\circ} 46^{\prime} 12^{\prime \prime}$ & $41^{\circ} 53^{\prime} 00^{\prime \prime}$ & $3360 \pm 180$ & $+1.80 \pm 0.40$ & Bah-1306 & Martin and Suguio, 1989 \\
\hline Buzios (RJ) & $22^{\circ} 44^{\prime} 18^{\prime \prime}$ & $41^{\circ} 51^{\prime} 18^{\prime \prime}$ & $3420 \pm 180$ & $+2.10 \pm 0.40$ & Bah-1304 & Martin and Suguio, 1989 \\
\hline Ilha Grande (RJ) & $23^{\circ} 10^{\prime}$ & $44^{\circ} 10^{\prime}$ & $3420 \pm 110$ & $+3.00 \pm 0.50$ & Gif-1059 & Delibrias and Laborel, 1969 \\
\hline Ilha do $\mathrm{Mel}(\mathrm{PR})$ & $25^{\circ} 32^{\prime} 20^{\prime \prime}$ & $48^{\circ} 17^{\prime} 26^{\prime \prime}$ & $3500 \pm 60$ & $+2.90 \pm 0.50$ & GSC -5255 & Angulo, 1992 \\
\hline Ponta do Retiro (RJ) & $21^{\circ} 21^{\prime} 34^{\prime \prime}$ & $40^{\circ} 57^{\prime} 37^{\prime \prime}$ & $3620 \pm 150$ & $+3.00 \pm 0.40$ & Bah-1008 & Martin and Suguio, 1989 \\
\hline Praia da Guaiuba (SP) & $24^{\circ} 00^{\prime} 54^{\prime \prime}$ & $46^{\circ} 17^{\prime} 42^{\prime \prime}$ & $3625 \pm 100$ & $+2.60 \pm 0.40$ & Bah-352 & Suguio and Martin, 1978a \\
\hline Cabo San Agostinho (PE) & $08^{\circ} 20^{\prime} 12^{\prime \prime}$ & & $3660 \pm 170$ & $+2.60 \pm 0.50$ & Shell-A22 & van Andel and Laborel, 1964 \\
\hline Gaibú (PE) & $08^{\circ} 19^{\prime} 05^{\prime \prime}$ & $34^{\circ} 56^{\prime} 43^{\prime \prime}$ & $3870 \pm 170$ & $+4.36 \pm 0.50$ & Bah-1221 & Dominguez et al., 1990 \\
\hline Cabo Frio $(\mathrm{RJ})$ & $22^{\circ} 54^{\prime} 16^{\prime \prime}$ & $42^{\circ} 00^{\prime} 00^{\prime \prime}$ & $3900 \pm 110$ & $+3.00 \pm 0.50$ & Gif-1934 & Delibrias and Laborel, 1969 \\
\hline Ponta de ltapiruba 2 (SC) & $28^{\circ} 20^{\prime} 18^{\prime \prime}$ & $48^{\circ} 41^{\prime} 57^{\prime \prime}$ & $3920 \pm 70$ & $+1.05 \pm 0.50$ & CENA-182 & Angulo et al., in prep. \\
\hline São $F^{c o}$. do Sul (SC) & $26^{\circ} 13^{\prime} 42^{\prime \prime}$ & $48^{\circ} 29^{\prime} 53^{\prime \prime}$ & $4015 \pm 90$ & $+3.05 \pm 0.50$ & GX-14060 & Angulo, 1989 \\
\hline Ponta do Ji 3 (SC) & $28^{\circ} 25^{\prime} 25^{\prime \prime}$ & $48^{\circ} 44^{\prime} 15^{\prime \prime}$ & $4060 \pm 70$ & $+2.00 \pm 0.50$ & CENA-191 & Angulo et al., in prep. \\
\hline Ponta de Itapiruba 3 (SC) & $28^{\circ} 20^{\prime} 18^{\prime \prime}$ & $48^{\circ} 41^{\prime} 57^{\prime \prime}$ & $4340 \pm 70$ & $+1.75 \pm 0.50$ & CENA-183 & Angulo et al., in prep. \\
\hline Ponta Azeda, Ilhabela- (SP) & $23^{\circ} 44^{\prime} 54^{\prime \prime}$ & $45^{\circ} 20^{\prime} 48^{\prime \prime}$ & $4455 \pm 145$ & $+1.90 \pm 0.40$ & Bah-461 & Suguio and Martin, $1978 \mathrm{a}$ \\
\hline Ponta Santo Amaro (SP) & $23^{\circ} 59^{\prime} 37^{\prime \prime}$ & $46^{\circ} 12^{\prime} 21^{\prime \prime}$ & $4480 \pm 180$ & $+3.00 \pm 0.50$ & Gif-2147 & Delibrias and Laborel, 1969 \\
\hline Passagem 1 (SC) & $28^{\circ} 30^{\prime} 19^{\prime \prime}$ & $48^{\circ} 44^{\prime} 45^{\prime \prime}$ & $4600 \pm 70$ & $+1.95 \pm 0.50$ & CENA-192 & Angulo et al., in prep. \\
\hline Caiobá (PR) & $25^{\circ} 51^{\prime} 06^{\prime \prime}$ & $48^{\circ} 32^{\prime} 04^{\prime \prime}$ & $4750 \pm 70$ & $+3.60 \pm 0.50$ & CENA-140 & Angulo, in prep. \\
\hline Morro da Sereia (BA) & & & $4970 \pm 150$ & +2.5 & Bah-579 & Martin et al., 1979a \\
\hline Santos (SP) & $23^{\circ} 52^{\prime} 18^{\prime \prime}$ & $46^{\circ} 50^{\prime} 48^{\prime \prime}$ & $5010 \pm 120$ & $+3.40 \pm 0.40$ & Bah-354 & Suguio and Martin, 1978a \\
\hline Porto da Barra (BA) & $12^{\circ} 59^{\prime} 48^{\prime \prime}$ & $38^{\circ} 51^{\prime} 48^{\prime \prime}$ & $5195 \pm 110$ & $+4.70 \pm 0.50$ & Bah-567 & Martin et al., 1979a \\
\hline Caiobá (PR) & $25^{\circ} 51^{\prime} 06^{\prime \prime}$ & $48^{\circ} 32^{\prime} 04^{\prime \prime}$ & $5300 \pm 70$ & $+3.45 \pm 0.50$ & CENA-141 & Angulo, in prep. \\
\hline Ponta da Galheta 4 (SC) & $28^{\circ} 34^{\prime} 00^{\prime \prime}$ & $48^{\circ} 47^{\prime} 11^{\prime \prime}$ & $5410 \pm 80$ & $+2.10 \pm 0.50$ & CENA-179 & Angulo et al., in prep. \\
\hline Poço de Anchieta (SP) & $24^{\circ} 32^{\prime} 00^{\prime \prime}$ & $46^{\circ} 48^{\prime} 36^{\prime \prime}$ & $6280 \pm 135$ & $+1.30 \pm 0.40$ & Bah-350 & Suguio and Martin, 1978a \\
\hline
\end{tabular}

last 6200 years, and show a consistent trend of falling sea level after a maximum around 5100 years B.P., with no indication of a secondary oscillation. Except for the shell-middens, the only evidence of a sea-level fall between 4100 and 3800 years B.P. in the whole Brazilian coast are the shells within beach-rocks found in Salvador
(Martin et al., 1979a) (Fig. 2a). Evidence to the contrary are five vermetid samples showing that sea level was above $+1 \mathrm{~m}$ during that interval (Fig. 11 and Table 3). It should be pointed out that the sample at $+4.5 \mathrm{~m}$ may have been made younger by post-depositional calcification, and its height could actually be related to the maximum 
PMT at 5100 years B.P. (Dominguez et al., 1990).

Palaeo-sea level interpretations based on shells from beach-rocks were based on primary sedimentary structures and textural grain size changes in the sediments (Flexor and Martin, 1979). It is argued that similar grain-size textural changes and structures, such as inclined plane-parallel stratifications either dipping sea- or landwards, can be produced in intertidal and subtidal environments, up to depths of 2-3 m (Short, 1984; Angulo, 1994). Therefore, palaeo-sea levels derived from such sources can be offset by several metres.

In regard to the time interval of the second proposed sea-level fall (3000-2700 years B.P.), we stress that it is based on data from only one site (Martin et al., 1979b) (Fig. 2a). The evidence is again a shell found within a beach-rock in the State of Bahia. In this case, eight vermetid dates of this age frame indicate that sea level was above $+1 \mathrm{~m}$ (Fig. 11 and Table 3 ). In short these vermetid data show a smooth decline in sea level (Fig. 11). Only in Salvador and Ilhéus is there evidence from sources other than shell-middens of a sea level lower than present. However, the nature of the dated material makes it prone to misinterpretation.

Observations in the Paranaguá and Cananéia regions show that maximum sea level at the PMT was not higher than $+4.0 \mathrm{~m}$, and was more likely around $3.5 \mathrm{~m}$. A vermetid sample from the Santos coastal plain gave a palaeo-sea level indication of about $+3.4 \mathrm{~m}$ some 100 years after the end of the PMT (Fig. 10b), and is in agreement with our proposed elevation for the maximum PMT. Three vermetid datings from the northern coast (Salvador, BA and Recife, PE) (Martin et al., 1979a; Dominguez et al., 1990) indicate that the Holocene sea-level maximum was higher than in the south, as has been postulated by Martin et al. (1985).

\section{Conclusion}

In the State of Paraná and south of São Paulo, vermetid samples as well as the elevation of the Pleistocene strandplains suggest that sea-level max- imum at the end of PMT was around $+3.5 \mathrm{~m}$, but not higher than $+4 \mathrm{~m}$.

The proposal of secondary sea-level oscillations along the Brazilian coast in the late Holocene has caused problems in the interpretation of the coastal geomorphology, especially due to the premise that such oscillations would be able to develop a new strandplain or barrier/lagoon systems. Given the existence of these sea-level oscillations, a numerical model suggested that the morphological response of the shoreline would more likely be a beach terrace encroached against the pre-existing barrier than another barrier/lagoon system.

Evidence of the secondary sea-level oscillations in the State of Paraná and south of the State of São Paulo, based exclusively on shell-midden data, is inconsistent and contradictory. Shell-middens are not reliable palaeo-sea level indicators, especially when they are located on palaeo-estuarine sediments, which are subject to compaction and dewatering due to its own load. Also, it is risky to assume that middens would be only built above high-tide levels, since the cultural aspect of an ancient population is difficult to assess.

An analysis of the vermetid data available in the literature for the Brazilian coast (93 samples) points to a smooth decline of the sea level since the end of the PMT at 5100 years B.P. Accordingly, the data do not support the existence of the secondary oscillations, or at least oscillations with a range of 4-5 m. Nine of the samples fall in the intervals of the proposed oscillations, all indicating palaeo-sea levels higher than $1 \mathrm{~m}$. The new trend suggested by the vermetid sea-level curve is more similar to the trends detected in other coastal regions of the Southern Hemisphere, where a smooth decline of sea level is observed after the Holocene post-glacial sea-level maximum.

\section{Acknowledgements}

We are thankful to Federico Ignacio Isla, Stephen Meyers, Paulo Cesar Giannini, Kenitiro Suguio and C.M. Clapperton for their comments on the manuscript. Bcrenice Valle is acknowledged for the drawing of most of the diagrams. The authors received financial support from the 
Brazilian Research Council (CNPq) and the FINEP/PADCT-UFPR project 'Evolução Geológica e Mineralizações-3’ (No. 65.91.03.03.00).

\section{References}

Angulo, R.J., 1989. Fossil Vermetidae between latitudes $25^{\circ} 34^{\prime} \mathrm{S}$ and $27^{\circ} 09^{\prime} \mathrm{S}$, State of Paraná and Santa Catarina - Brazil. Int. Symp. Global Changes in South America During the Quaternary, São Paulo, Spec. Publ. 1, pp. 263-268.

Angulo, R.J., 1992. Geologia da Planície Costeira do Estado do Paraná. Ph.D. Thesis, Instituto de Geociências, Universidade de São Paulo, 332 pp.

Angulo, R.J., 1993. Indicadores biológicos de paleoníveis marinhos quaternários na costa paranaense. Bol. Parana. Geocien. 41, 1-34.

Angulo, R.J., 1994. Indicadores morfológicos e sedimentológicos de paleoníveis marinhos quaternários na costa paranaense. Bol. Parana. Geocienc. 42, 185-202.

Angulo, R.J., (in prep.). Radiocarbon datings from the State of Parana and paleo-sea level reconstructions.

Angulo, R.J., Giannini, P.C.F. 1997. Variação do nível relativo do mar nos últimos dois mil anos na regiào sul do Brasil: Uma discussão. Bol. Parana. Geocien. 44 (in press)

Angulo, R.J., Suguio, K., 1995. Re-evaluation of the Holocene sea-level maxima for the State of Paraná, Brazil. Palaeogeogr., Palaeoclimatol., Palaeoecol. 113, 385-393.

Angulo, R.J., Giannini, P.C.F., Suguio, K., Pessenda, L.C.R. (in prep.). Variação nível relativo do mar nos últimos 5500 anos na região de Laguna-Imbituba (Santa Catarina), com base em dataçðes radiocarbônicas de tubos de vermetídeos.

Barcelos, J.H., 1975. Sedimentação e Subambientes Deposicionais da Ilha Comprida, São Paulo. M.Sc. Thesis, Instituto de Geociências, Universidadde de São Paulo, 155 pp.

Bigarella, J.J., 1946. Contribuição ao estudo da planície litorânea do Estado do Paraná. Arq. Biol. Tecnol. 1, 75-111.

Bigarella, J.J., 1971. Variações climáticas no Quaternário Superior do Brasil e sua datação radiométrica pelo método do carbono 14. Paleoclimas 1, 1-22.

Bigarella, J.J., Salamuni, R. and Marques F', P.L. 1961. Método para avaliação do nível oceânico à época da formação dos terraços de construção marinha. Boletim Paranaense Geografia, 4- and 5:11-115.

Bigarella, J.J., Becker, R.D., de Matos, D.J., Werner, A. (Eds.), 1978. A Serra do Mar e a porção oriental do Estado do Paraná: um problema de segurança ambiental e nacional. Gov. Par./SEPL/ADEA, Curitiba, 249 pp

Bittencourt, A.C. da S.P., Martin, L., Vilas Boas, G. da S., Flexor J.M., 1979 Quaternary marine formations of the coast of the State of Bahia (Brazil). Proc. Int. Symp. Coastal Evolution in the Quaternary, São Paulo, 1979. São Paulo, pp. 232-253.

Cowell, P.J., Roy, P.S., Jones, R.A., 1992. Shoreface translation model: computer simulation of coastal-sand-body response to sea level rise. Math. Comput. Simulation 33, 603-608.
Cowell, P.J., Roy, P.S., Jones, R.A., 1995. Simulation of large scale coastal change using a morphological behaviour model. Mar. Geol. 126, 45-61.

Delibrias, C., Laborel, J,, 1969. Recent variations of the sea level along the Brazilian coast. Quaternaria 14, 45-49.

Dias, G.T.M., 1981. O compolexo deltaico do rio Paraíba do Sul (Rio de Janeiro). IV Simpósio Brasileiro do Quaternário, IV Brazilian Quaternary Symp. Spec. Publ. 2, CTCQ/SBG, Rio de Janeiro, pp. 58-88.

Dominguez, J.M.L., Bittencourt, A.C.S.P., Martin, L., 1981. Esquema evolutivo da sedimentação quaternária nas feições deltaicas dos rios São Francisco (SE/AL), Jequitinhonha (BA), Doce (ES) e Paraíba do Sul (RJ). Rev. Bras. Geocien. 11 (4), $227-237$.

Dominguez, J.M.L., Bittencourt, A.C.S.P., Leão, Z.M.A.N., Azaevedo, A.E.G., 1990. Geologia do Quaternário costeiro do estado de Pernambuco. Rev. Bras. Geocien. 20 (1-4), 208-215.

Fairbridge, R.W., 1962. World sea level and climatic changes. Quaternaria 6, 111-134.

Flexor, J.M., Martin, L., 1979. Sur l'utilisation des grès coquilliers de la région de Salvador (Brésil) dans la reconstruction des lingnes de rivages Holocènes. Proc. Int. Symp. Coastal Evolution in the Quaternary. IGCP, São Paulo, pp. 343-355.

Hoyt, J.H., 1967. Barrier island formation. Geol. Soc. Am. Bull. $78,1125-1136$.

Isla, F.I., 1989. Holocene sea-level fluctuation in the Southern Hemisphere. Quat. Sci. Rev. 8, 359-368.

Kraft, J.C., John, C.J., 1979. Lateral and vertical facies relations of transgressive barrier. Am. Assoc. Pet. Geol. Bull. 63, 2145-2163.

Laborel, J., 1979 Fixed marine organisms as biological indicator for the study of recent sea level and climatic variations along the Brazilian tropical coast. Proc. Int. Symp. Coastal Evolution in the Quaternary. IGCP, São Paulo, pp. 193-211.

Laborel, J., 1986. Vermetid gastropods as sea-level indicators. In: van de Plassche, O. (Ed.), Sea-Level Research: A Manual for the Collection and Evaluation of Data. Geo Books, Norwich, pp. 281-310.

Laming-Emperaire, J., 1968. Missions archéologiques françaises au Chili austral et au Brésil méridional: datations de quelques sites par le radiocarbone. J. Soc. Américan. 57, 77-99.

Lessa, G.C., Angulo, R.J., 1995. A framework for the stratigraphy and evolution of the Paranaguá coastal plain-Paraná, Brazil. In: Anais V Congresso da Associação Brasileira de Estudos do Quaternário. Proc. VII Congress of the Brazilian Association of Quaternary Studies, ABEQUA, Niterói, pp. 92-98.

Lessa, G.C. and Angulo, R.J. (in prep.). A 3-D model for the evolution of the Paranaguá coastal plain

Maia, M.C.A.C., Martin, L., Flexor, J.M., Azevedo, A.E.G., 1984. Evoluçào holocênica da planicie costeira de Jacarepaguá (RJ). Proc. XXXIII Bras. Geol. Congr., SBG, Rio de Janeiro, 1, pp. 105-118. 
Martin, L., Suguio, K., 1976. O Qualernário marinho do litoral do Estado de São Paulo. Proc. XIX Congr. Bras. Geol., SBG, Belo Horizonte (MG), 1, pp. 281-294.

Martin, L., Suguio, K., 1978. Excursion rout along the coastline between the town of Cananéia (State of São Paulo) and Guaratiba outlet (state of Rio de Janeiro). Int. Symp. Coastal Evolution, São Paulo, 1978. Spec. Publ. São Paulo, IG, USP, SBG, 2, 98 pp.

Martin, L., Suguio, K., 1989. Excursion Route along the Brazilian Coast Between Santos (SP) and Campos (RJ) (North of State of Rio de Janeiro). Int. Symp. Global Changes in South America During the Quaternary. Spec. Publ. 2, ABEQUA-INQUA, São Paulo, 136 pp.

Martin, L., Flexor, J.M., Boas, G.S.V., Bittencourt, A.C.S.P., Guimarães, M.M.M., 1979a. Courbe de variation du niveau relatif de la mer au cours des 7000 derniéres années sur un secteur homogéne du littoral brésilien (nord de Salvador Bahia). Proc. Int. Symp. Coastal Evolution in the Quaternary., IGCP, São Paulo, pp. 296-331.

Martin, L., Suguio, K., Flexor, J.M., 1979b. Le Quaternaire marin du littoral brésilien entre Cananéia (SP) et Barra de Guaratiba (RJ). Proc. Int. Symp. Coastal Evolution in the Quaternary, IGCP, São Paulo, pp. 296-331.

Martin, L., Bittencourt, A.C.S.P., Flexor, J.M., Vilas-Boas, G.S., 1984. Evidência de um tcctonismo quaternário nas costas do Estado da Bahia. Proc. XXXIII Congr. Bras. Geol. SBG, Rio de Janeiro, 1, pp. 19-35.

Martin, L., Suguio, K., Flexor, J.M., Dominguez, J.M.L., de Azevedo, A.E.G., 1984b. Evolução da planície costeira do rio Paraiba do Sul ( $R J$ ) durante o Quaternário: Influência das flutuaçòes do nível do mar. Proc. XXXIII Congr. Bras. Geol., Rio de Janeiro, 1, pp. 84-97.

Martin, L., Flexor, J.M., Blitzkow, D., Suguio, K., 1985. Geoid change indications along the brazilian coast during the last 7,000 years. Proc V Int. Congr. Coral Reef, Tahiti, 3, pp. 85-90.

Martin, L., Suguio, K., Flexor, J.M., 1986. Shell middens as a source for additional information in Holocene shoreline and sea-level reconstruction: examples from the coast of Brazil. In: Van de Plasseche, O. (Ed.), Sea-Level Research: A Manual for the Collection and Evaluation of Data. Free Univ. Amsterdam, Amsterdam, pp. 503-521.

Martin, L., Suguio, K., Flexor, J.M., Azevedo, A.E.G., 1988. Mapa geológico do Quaternário costeiro dos Estados do Paraná e Santa Catarina. Série Geol. DNPM. Brasilia, 28, $40 \mathrm{pp}$.

Muehe, D., Corrêa, C.H.T., 1988. Os 'arenitos de restinga' do cordão litorâneo da Maçambaba/Lagoa de Araruama RJ. Proc. XXXIV Congr. Bras. Geol, SBG, Belém, 2, pp. 553-561.

Muehe, D., Ignarra, S., 1984 Arenito de praia submerso em frente à praia de Itaipuacú -RJ. Proc. XXXIII Congr. Bras. Geol., SBG, Rio de Janeiro, 2, pp. 341--346.

Neto, R.C.. 1984. Algumas considerações sobre a origem do sistema lagunar de Araruama. In: Lacerda, L.D. et al. (Eds.), Restingas - Origem, Estruturas, Processos. UFF, Rio de Janeiro, pp. 61-63.
Perrin, P., 1984. Evolução da costa fluminense entre as pontas de Itacoatiara e Negra. Preenchimentos e restingas. In: Lacerda, L.D. et al. (Eds.), Restingas - Origem, Estruturas, Processos. UFF, Rio de Janeiro, pp. 65-73.

Petri, S., Suguio, K., 1973. Stratigraphy of the Iguape Cananéia lagoonal region sedimentary deposits, São paulo, Brazil, Part 2. Heavy mineral studies, microorganisms inventories and stratigraphical interpretations. Bol. IG-USP, Inst. Geocien. 4, 71-85.

Pirazzoli, P.A., 1991. World Atlas of Holocene Sea-Level Changes. Oceanography Series, 58, Elsevier, Amsterdam, $300 \mathrm{pp}$.

Ponçano, W.L., 1981. As coberturas cenozóicas. In: Almeida, F.F.M. et al. (Eds.), Mapa Geológico do Estado de São Paulo na escala 1:500,000. Instituto de Pesquisas Tecnológicas, São Paulo, Publ. 1184, 1, pp. 82-96.

Rivereau, J.C., Fuck, R.A., Muratori, A., Trcin, E., 1968. Ilha do Mel, Folha Geológica. Comissão da Carta Geológica do Paraná, Curitiba, Escala 1:70.000.

Rivereau, J.C., Fuck, R.A., Muratori, A., Trein, E., 1969 a. Barra do Ararapira, Guaratuba, Paranaguá, Pedra Branca de Araraquara, Guaraqueçaba, Folhas Geológicas. Comissão da Carta Geológica do Paraná, Curitiba, Escala 1:70.000.

Rivereau, J.C., Fuck, R.A., Muratori, A., Trein, E., $1969 \mathrm{~b}$. Guaratuba, Folha Geológica. Comissão da Carta Geológica do Paraná, Curitiba, Escala 1:70.000.

Rivereau, J.C., Fuck, R.A., Muratori, A., Trein, E., 1969c. Paranaguá, Folha Geológica. Comissão da Carta Geológica do Paraná, Curitiba, Escala 1:70.000.

Rivereau, J.C., Fuck, R.A., Muratori, A., Trein, E., 1969d. Pedra Branca de Araraquara, Folha Geológica. Comissão da Carta Geológica do Paraná, Curitiba, Escala 1:70.000.

Rivereau, J.C., Muratori, A., Trein, E., Fuck, R.A., Hausen, J.P., Basumallick, S., 1969e. Guaraqueçaba, Folha Geológica. Comissão da Carta Geológica do Paraná, Curitiba, Escala 1:70.000.

Rivereau, J.C., Trein, E., Muratori, A., Fuck, R.A., Basumallick, S., Bertoldo, A.L., 1970. Antonina, Folha Geológica. Comissão da Carta Geológica do Paraná, Curitiba, Escala 1:70.000.

Roep, Th.B., 1986. Sea-level markers in coastal barrier sands: examples from the North Sea coast. In: van de Plassche, $O$. (Ed.), Sea-Level Research: A Manual for the Collection and Evaluation of Data. Geo Books, Norwich, pp. 97-128.

Roy, P., Cowell, P.J., Ferland, M.A., Thom, B.G., 1995. Wave dominated coasts. In: Carter, R.W.G., Woodroffe, C.D. (Eds.), Coastal Evolution. Cambridge University Press, pp. $121-186$.

Short, A.D., 1984. Beach and nearshore facies: southeast Australia. Mar. Geol. 60, 261-282.

Silva, G.C., 1987. Complexo deltaico do rio Paraíba do Sul. Proc. I Symp. Regional Geology, RJ-ES. SBG, Rio de Janeiro, pp. 299-346

Soares, R.S., Paranhos Fo, A.C., Souza, M.C. de Branco, J.C., Fabianovicz, R., Prazeres Fo, H.J., Kogut, J.S., 1994, Variações da linha de scosta no balneário de Pontal do Sul (PR) 
no período de 1953-1993, um balanço sedimentar. Bol. Parana. Geocien. 42, 161-171.

Souza, L.A.P., 1995. A Planície Costeira Cananéia-Iguape, Litoral Sul do Estado de São Paulo: um Exemplo de Utilização de Métodos Geofísicos no Estudo de Areas Costeiras. M.Sc. Thesis, Instituto Oceanográfico, São Paulo University, $207 \mathrm{pp}$.

Suguio, K., Barcelos, J.H., 1978. Quaternary sedimentary environments in Comprida Island, State of São Paulo, Brazil. Bol. IG-USP, Inst. Geocien. 9, 203-211.

Suguio, K., Martin, L., 1976. Brazilian coastline quaternary formations the States of São Paulo and Bahia littoral zone evolutive schemes. Anais Acad. Bras. Cien. 48 (Suppl.), 325-334.

Suguio, K., Martin, L., 1978a. Formações quaternária marinhas do litoral paulista e sul fluminense. Int. Symp. Coastal Evolution in the Quaternary-The Brazilian National Working Group for the IGCP, Project 61. Instituto de Geociências da USP, Spec. Publ. 1.

Suguio, K., Martin, L., 1978b. Mapa geológico do litoral paulista, folhas Cananéia e Iguape (1:100,000). São Paulo.

Suguio, K., Petri, S., 1973. Stratigraphy of the IguapeCananéia lagoonal region sedimentary deposits, São Ppaulo, Brazil, Part 1. Field Observations and grain size analysis. Bol. IG-USP, Inst. Geocien. 4, 1-20.

Suguio, K., Martin, L., Flexor, J.M., 1976. Les variations rélatives du niveau moyen de la mer au quaternaire récent dans la région de Cananéia-Iguape, São Paulo. Bol. IG-USP, Inst. Geocien. 7, 113-129.
Suguio, K., Martin, L., Bittencourt, A.C.S.P., Dominguez, J.M.L., Flexor, J.M., Azevedo, A.E.G., 1985. Flutuações do nivel relativo do mar durante o Quaternário Superior ao longo do litoral brasileiro e suas implicaçōes na sedimentação costeira. Rev. Bras. Geocien. 15 (4), 273-286.

Suguio, K., Martin, L., Flexor, J.M., 1988. Quaternary sealevels of the Brazilian coast: recent progress. Episodes 11 (3), 203-208.

Tessler, M.G., 1988. Dinâmica Sedimentar Quaternária no Litoral Sul Paulista. Ph.D. Thesis, Instituto de Geociências, Universidade de São Paulo, 276 pp.

Tomazelli, L.J., 1990. Contribuição ao estudo dos sistemas deposicionais holocênicos do nordeste da província costeira do Rio Grande do Sul, com ênfase no sistema eólico. Ph.D. Thesis, Universidade Federal do Rio Grande do Sul, $270 \mathrm{pp}$.

Turq, B., Coe, R., Froidefond, J.M., 1986. Variability of beach ridges on the coast of Maricá (Rio de Janeiro, Brazil). In: Rabassa, J. (Ed.), Quaternary of South America and Antarctic Peninsula. A.A. Balkema, Rotterdam, Vol. 4, pp. 45-57.

van Andel, T.H., Laborel, J., 1964. Recent high relative sea level stand near Recife, Brazil. Science 145, 580-591.

Villwock, J.A., Tomazelli, L.J., 1989. Sea-level changes and Holocene evolution in Rio Grande do Sul coastal plain, Brazil. Int. Symp. Global Changes in South America During the Quaternary: Past-Present-Future. Spec. Publ. 1, INQUA-ABEQUA São Paulo, pp. 192-196. 